\title{
The Blind Men and the Elephant: Towards an Organization of Epistemic Contexts ${ }^{\dagger}$
}

\author{
Michael Kleineberg \\ Berlin School of Library and Information Science, Humboldt-Universität zu Berlin, \\ Unter den Linden 6, 10099 Berlin, Germany <michael.kleineberg@ibi.hu-berlin.de>
}

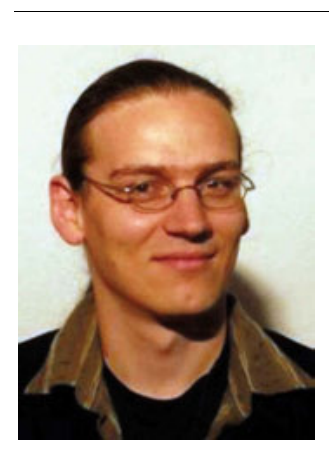

Michael Kleineberg is a researcher at the Berlin School of Library and Information Science (BSLIS). He studied cultural studies, sociology, philosophy, German literature, and obtained a master's degree in library and information science (LIS). He is a second year PhD student at the Berlin School in the information retrieval group and participates in the European PROMISE project. His research area is the theory of knowledge organization, in particular the social influence on classification and concept development.

Kleineberg, Michael. The Blind Men and the Elephant: Towards an Organization of Epistemic Contexts. Knowledge Organization. 40(5), 340-362. 91 references.

ABSTRACT: In the last two decades of knowledge organization (KO) research, there has been an increasing interest in the context-dependent nature of human knowledge. Contextualism maintains that knowledge is not available in a neutral and objective way, but is always interwoven with the process of knowledge production and the prerequisites of the knower. As a first step towards a systematic organization of epistemic contexts, the concept of knowledge will be considered in its ontological (WHAT) and epistemological (WHO) including methodological (HOW) dimensions. In current KO research, however, either the contextualism is not fully implemented (classification-as-ontology) or the ambition for a context-transcending universal KOS seems to have been abandoned (classification-as-epistemology). Based on a combined ontology and epistemology it will be argued that a phenomena-based approach to $\mathrm{KO}$ as stipulated by the León Manifesto, for example, requires a revision of the underlying phenomenon concept as a relation between the known object (WHAT) and the knowing subject (WHO), which is constituted by the application of specific methods (HOW). While traditional subject indexing of documents often relies on the organizing principle "levels of being" (WHAT), for a future context indexing, two novel principles are proposed, namely "levels of knowing" (WHO) and "integral methodological pluralism" (HOW).

† This contribution is based on a translation of a conference paper presented at the $13^{\text {th }}$ Meeting of the German ISKO "Theory, Information, and Organization of Knowledge," Potsdam, 19 March 2013. The author would like to thank Peter Ohly, Vivien Petras and Birger Hjørland for their support to improve the quality of this paper.

Received 2 May 2013; Accepted 16 May 2013

\subsection{Introduction}

The story is old and well-known. In one of its many versions, seven blind men examine an elephant focusing on seven different aspects. The result is seven completely incommensurable descriptions of the very same object of interest. The moral seems to be quite obvious: all these partial truths could be integrated within a bigger picture so long as you have eyes to transcend your own limited perspective. Thus the parable The Blind Men and the Elephant illustrates the plurality of epistemic contexts and the related problem of relativism with regard to human knowledge. But like every story, this one is open to different interpretations.
The concept of context (Latin: contextus from contexere = "to weave together," "interwoven") should itself be considered in context since its meaning ranges between two fundamental opposites as a "dichotomization between objectified and interpretive approaches to context" (Talja et al. 1999, 761). Aligned with such a stereotypical understanding of two poles of a continuum, we can find the same distinction within current research on knowledge organization $(\mathrm{KO})$ in the separation of two camps which might be labeled as "modernism" (classification-as-ontology) versus "postmodernism" (classification-as-epistemology) (Mai 1999, 2011; Szostak 2007).

The "modernist" approaches tend toward a weak interpretation of the elephant parable seeing the manifold 
M. Kleineberg. The Blind Men and the Elephant: Towards an Organization of Epistemic Contexts

perspectives merely as different aspects of one and the same neutral phenomenon. These ontologically oriented theories consider the known object (the WHAT of knowledge) as something pre-given and completely independent from any observer. In this view, a main goal is to classify the totality of entities or phenomena in a universal and often faceted knowledge organization system (KOS) as neutral and objective as possible (Dahlberg 1974; Poli 1996; Szostak 2007; Gnoli 2011).

In contrast, the "postmodernist" approaches favor a much stronger interpretation emphasizing that observers from different perspectives "see" different phenomena indeed. In this view, the elephant as a metaphor for reality is seen as a social construction depending on the observer's cultural and historical background. As a consequence, the development of context-transcending or even universal KOS's is regarded rather skeptically. These epistemologically oriented theories consider phenomena not merely as pre-given but as constructed by knowing subjects (the WHO of knowledge) which are always situated in horizons of epistemic cultures seen as practice and discourse communities which constitute their own forms of life, language-games, and worldviews (Hjørland 2008; Olson 2010; Mai 2011; Smiraglia 2012).

In this paper, it will be argued that both approaches, although not all mentioned theorists maintain a pure "modernist" or postmodernist" position as we will see, are not sufficient to cope with the challenges of an inter- or transdisciplinary approach to $\mathrm{KO}$ as it is legitimately proclaimed, particularly by the León Manifesto (www.iskoi. org/ilc/leon.php) (ISKO Italy 2007). As a programmatic outcome of the $8^{\text {th }}$ conference of the Spanish chapter of the International Society of Knowledge Organization (ISKO), the León Manifesto proposes a phenomena-based, instead of discipline-based, approach to classification theory which has, of course, its historical precursor in the medieval distinction between "ordo disciplinarum" versus "ordo rerum” (Rötzer 2003, 113-122). In current KO research, however, either the perspectivism of a classification-as-epistemology or the universal scope of a classification-as-ontology seem to be neglected. Based on these premises, a systematic organization of epistemic contexts appears as highly problematic. Dervin $(2003,130)$ writes:

Admittedly in this discussion I have refused to be cowed by the polarized arguments of either the more postmodern contextualists who see nothing but tyranny in systematization, or the more modern contextualists who see nothing but chaos in a fully implemented contextualism.

As an alternative, an integrative approach is proposed based on a combination of ontology and epistemology which might be termed "constructive realism" (Dux 2011, 148). In this view, knowledge is seen as both a human construction and, to some extent, a reflection of reality which is partially independent from human observers. The essential consequence for phenomena-based KOS's such as the Information Coding Classification (Dahlberg 2008) or the Integrative Levels Classification (www.iskoi.org/ilc) (Gnoli 2011) is a revision of the underlying concept of phenomenon. It will be argued that each phenomenon should be considered as a relation between a known object (WHAT) and a knowing subject (WHO) which is constituted by the application of specific methods (the HOW of knowledge). In other words, phenomena are not seen as independent of the observer but related to perspectivism. EsbjörnHargens and Zimmerman (2009, 35) write:

Perspectivalists maintain that mind-far from being a mirror that passively receives independent phenomena-plays an active role in co-constructing phenomena. Methodologies not only reveal, but also in some respect constitute the phenomena under investigation. What we call "facts," in other words, are not ready-made but emerge in a complex process of perceptual, emotional, and cognitive negotiation between knower and known.

As a consequence, in $\mathrm{KO}$ theory the ontological dimension should be seen as inextricably interwoven with the epistemological (including methodological) dimension. Each of them demands a systematic organization based on solid organizing principles; therefore, traditional content or subject indexing (WHAT) should be complemented by something tentatively termed "context indexing," which takes the viewpoints of the knowing subjects (WHO) as well as the applied methods (HOW) into account. While there seems to be a large agreement between "modernists" and "postmodernists" on the potential benefit of a context indexing, adequate organizing principles are rarely introduced (Weinberg 1988; Begthol 1998; Mai 2003; Szostak 2003; Hjørland 2008; Gnoli 2011).

As a theoretical foundation for a systematic organization of epistemic contexts, cybersemiotics developed by Danish information scientist Søren Brier $(2008,143)$ offers a non-reductionist approach to a "transdisciplinary integration of knowledge from different viewpoints, methods and subjects areas." Likewise, integral theory developed by American philosopher Ken Wilber (2000b) is widely compatible with the cybersemiotic approach and offers a framework for a comprehensive analysis of the ontological, epistemological, and methodological dimensions of knowledge.

The main goal of this paper is to demonstrate that an implementation of perspectivism and contextualism in 
any phenomena-based KOS requires a revision of the underlying concept of phenomenon as a triadic relation between the WHAT, the WHO, and the HOW of knowledge.

\subsection{The WHAT of knowledge: ontology}

If the elephant is a metaphor for reality, then the blind men represent the epistemic contexts, i.e., the circumstances of knowledge production which constitute the preconditions and limitations of human knowledge. Esbjörn-Hargens and Zimmerman $(2009,15)$ write:

what someone calls 'reality' depends on What part of reality one is examining, Who is doing the examining, and How they examine (or which methods they use).

Although these three dimensions seem to be closely related and equally important, the ontological question for the WHAT of knowledge will be the first one addressed.

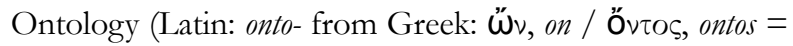
"being," "that which is") is the study of being and how reality is constituted and structured. Ontological theories are typically concerned with entities, things, objects, phenomena, properties, structures, elements, processes, or simply beings. To keep within the elephant picture, there is a plethora of phenomena ranging from anatomy to brain physiology to DNA sequence to food habits to herd behavior or even psychopathology. One of the main tasks of a comprehensive KOS is to integrate all these topics or knowledge subjects in a systematic way indicating their thematic interconnectedness.

The point of departure for ontologically-oriented approaches is that reality itself underlies a certain structure which can be adopted as organizing principle for KOS's based on entities or phenomena. In $\mathrm{KO}$ theory, there exists a long and today widely spread tradition of relying on the concept of "levels of being" (Dahlberg 2008, 163) also known as "levels of reality" or "integrative levels" (Austen 1969; Huckaby 1972; Foskett 1978; Spiteri 1995; Gnoli and Poli 2004; ISKO Italy 2007; Szostak 2007; Dahlberg 2008). Gnoli (2008, 178-79) writes:

One suitable principle to classify phenomena independently from disciplines has been found to be the notion of integrative levels, also referred to as "levels of organization" or (less accurately) "levels of complexity." These terms refer to the observation that world phenomena belong to different ontological levels, spanning from the material, to the organic, the mental, and the cultural.
The basic idea is that cosmic evolution emerges in levels of increasing complexity and integration at which each higher level includes and transcends the lower levels (Blitz 1992). This is the reason why the integrative levels, often depicted as a hierarchy of concentric circles, are following a chronological order. A simple example is given by the sequence atom-molecule-cell-organism (Feibleman 1954). The integrative character of such levels can be illustrated with the elephant, which as an organism is composed of cells which themselves are composed of molecules and so on. Interestingly, most discipline-based KOS's rely implicitly on the notion of evolutionary order and the levels of being manifested in a typical sequence such as physics—chemistry-biology—psychology—social sciences/humanities (Dousa 2009).

One of the earliest attempts to develop a universal KOS based on entities or phenomena are the works by the Classification Research Group (CRG) during the 1960s. The basic schema of the proposed New General Classification is explicitly oriented on the organizing principle of "integrative levels" (see Figure 1 based on Huckaby 1972, 101-02).

The motivation for the development of phenomenabased approaches to $\mathrm{KO}$ is to overcome the constraints of the prevailing discipline-based classifications, in particular, their under-determined attribution of documents or knowledge subjects to one single classification entry as well as the adaptation of new scientific developments (Foskett 1978; ISKO Italy 2007). The decisive advantage of a phenomena-based KOS is seen in its nature as a “"one place' classification” (Hjørland 2008, 338), which enables a non-redundant organization of entities often used as point of reference for further facets (Gnoli 2008, 2011; Gnoli and Szostak 2009).

The basic schema of the New General Classification proposed by the CRG is based on phenomena, but is not developed to a final and applicable version since the organizing principle of integrative levels appears to be inconsistent because of various branching and dead-ends within the hierarchical classificatory structure (Huckaby 1972; Spiteri 1995).

The foundational work of the CRG inspired some following endeavors such as the Information Coding Classification (ICC) developed in the 1970s by Ingetraut Dahlberg. In ICC, the main classes are organized according to nine levels of being. Dahlberg (2008, S163) lists them as follows:

General forms and structures

Matter and energy

Aggregated matter (cosmos and earth)

Biological objects (micro-organisms, plants, animals)

Human Beings 
M. Kleineberg. The Blind Men and the Elephant: Towards an Organization of Epistemic Contexts

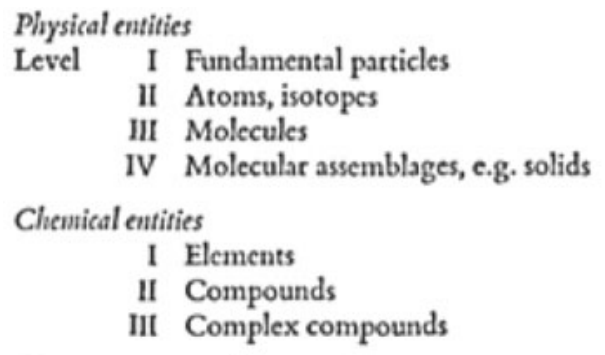

Heterogeneous non-living entitics

I Minerals

II Rocks

III Physiographic features

IV Astronomical entities

Artefarts

I Raw materials

II Processed raw materials

III Components

IV Finished articles

Biological entities

I Viruses
II Organelles
III Cells
IV Tissues
V Organs
VI Systems, c.g. digestive systems
VII Organisms
VIII Communities, e.g. shoal, herd

Man

1 Individual

II Group

III Local community

IV National community

V International community

Mentefacts

I Units, c.g., digit, note

II Words, numbers, bars, etc.

III Sentences, formulae, musical phrases, ctc.

IV Paragraphs, themes, etc.

V Complete works, philosophical systems, ctc.

Figure 1. CRG basic schema

Societal Beings

Material products of mankind (products of economy and technology)

Intellectual products (scientific, information and communication products)

Spiritual products (language, literature, music, arts, etc.).

In opposition to the CRG's level model, the ICC classifies material artifacts after biological entities, since they depend on the historical appearance of human beings. Nevertheless, the human related main classes (5-9) seem to violate both the chronological and the integrative principle. On the one hand, areas such as technology, science,

\begin{tabular}{|c|c|c|}
\hline Layers & Strata & Hartmann \\
\hline A forms & Form & Logical \\
\hline C spaces & \multirow[t]{8}{*}{ Matter } & \multirow[t]{8}{*}{ Material } \\
\hline D particles & & \\
\hline E atoms & & \\
\hline F molecules & & \\
\hline G bulk matter & & \\
\hline I celestial obj. & & \\
\hline $\mathrm{J}$ rocks & & \\
\hline $\mathrm{K}$ landforms & & \\
\hline L cells & \multirow[t]{3}{*}{ Life } & \multirow[t]{3}{*}{ Organic } \\
\hline$M$ organisms & & \\
\hline $\mathrm{N}$ populations & & \\
\hline$O$ instincts & \multirow{3}{*}{ Mind } & \multirow[t]{3}{*}{ Psychic } \\
\hline P consciousness & & \\
\hline Q signals & & \\
\hline R social welfare & \multirow[t]{5}{*}{ Society } & \multirow[t]{5}{*}{ Spiritual } \\
\hline $\mathbf{S}$ land products & & \\
\hline$T$ artifacts & & \\
\hline$U$ wealth & & \\
\hline V organizations & & \\
\hline W cultures & \multirow[t]{4}{*}{ Culture } & \multirow[t]{4}{*}{ Spiritual } \\
\hline $\mathrm{X}$ art works & & \\
\hline Y knowledge & & \\
\hline $\mathrm{Z}$ wisdom & & \\
\hline
\end{tabular}

Figure 2. ILC basic schema and language are interdependent and should be considered as developing not in a linear sequence but in coevolution. On the other hand, intellectual products like literature and music are not composed of societal beings or material products in the same way as molecules are composed of atoms. These kinds of problems challenge most phenomena-based KOS's organized according to the principle of levels of being as is the case with the international project Integrative Levels Classification (ILC), which adopts the underlying organizing principle for its own title (Gnoli 2008). The development of the ILC's basic schema is inspired by James Feibleman's (1954) "laws of the levels" and by Nicolai Hartmann’s (1953) categorical analysis (see Figure 2 based on Gnoli 2008, 184). 
The basic problems of applying the integrative levels principle in a coherent way are discussed particularly by Claudio Gnoli and Roberto Poli in their explicit ontological approach to knowledge organization (Gnoli 2008; Poli 1996, 1998, 2001, 2006; Gnoli and Poli 2004). Gnoli (2008, 187) writes:

While material and organic levels can be arranged in a linear sequence quite easily, mental, social, and cultural levels look more 'tangled.'

For example, mental phenomena such as perceptions, emotions, or thoughts seem to be categorically different from both material phenomena (interior versus exterior) and social phenomena (individual versus collective). Following Hartmann's ontology, Gnoli and Poli argue to diminish the level concept in distinguishing between truly integrative levels ("layers") and non-integrative levels ("strata"), although it is recognized that the "relation between strata generally remains unanalyzed and quite mysterious" (Gnoli 2008, 185). Furthermore, their proposed level model seems not to be appropriate for social or cultural phenomena at all (see Figure 3 based on Poli 1998, 203).

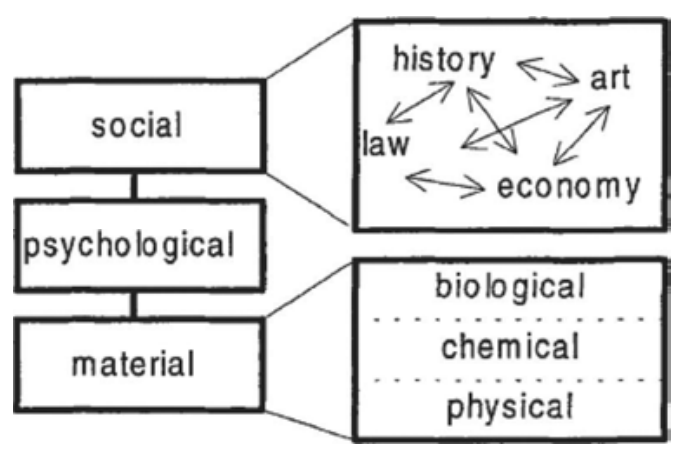

Figure 3. Integrative and non-integrative levels

These inconsistencies of the underlying level model are seen as open problems and challenges for recent classification research, although Poli considers also alternative principles for modeling levels of being. The first alteration might be called the principle of co-evolution. Poli (2001, 173-74) writes:

I wish at least to suggest that a different opinion is possible ... that the realm of material phenomena acts as the basis, as the bearer, of both mental and social phenomena. In their turn, the realms of mental and social phenomena reciprocally determine each other. The underlying idea is that there are no societies without minds, just as there are no minds without corresponding societies. Put otherwise, mental and social systems are formed through co- evolution: the one is the environment prerequisite for the other.

The second alteration might be called the principle of panpsychism. Poli $(2001,280)$ continues:

The reductionist approach has historically relied on the help of a materialistic metaphysics. The different orientation offered by the theory of the levels may likewise rely on the support provided by a different metaphysics - in this case, a panpsychist theory which holds that the ultimate nature of the universe is that of a society of minds. Before this view is held up for ridicule, it should be remembered that it has been put forward by no less thinkers than Leibniz, Brentano and Whitehead.

In the following, an alternative level model will be introduced, which takes these two principles into account. Both of them have historical precursors; the principle of coevolution is emphasized, for example, by William Morton Wheeler or George Herbert Mead, while the principle of panpsychism is postulated particularly by Conwy Lloyd Morgan (Blitz 1992). The proposed AQAL model (akronym for "All Quadrants, All Levels") is developed by Ken Wilber as the core element of his integral theory and offers, at the price of a radical divergent ontology, a more consistent model of levels of being (Wilber 1997, 2000a, 2000b).

Integral theory, quite similar to cybersemiotics, is an attempt to integrate knowledge across disciplines and domain-specific perspectives in order to enhance transdisciplinary research. The concept of transdisciplinarity (Latin: trans- = "across," "over," "beyond"), which following Erich Jantsch "signifies the interconnectedness of all aspects of reality" (Klein 1980, 66), covers also the connotation intended by its inventor, the Swiss philosopher Jean Piaget, not merely to embrace all disciplines but also to transcend scientific knowledge as such (Nicolescu 2010; for the derived concept of "postdisciplinarity," see Esbjörn-Hargens 2006, 82). This means to honor also non-scientific knowledge forms such as mythic narratives and other folk knowledge which contribute a remarkable amount to the cultural heritage we collect and organize in our memory institutions such as libraries, museums, and archives.

In opposition to linear level models, the AQAL model is divided into four main areas of phenomena or quadrants based on two fundamental distinctions reflecting the categorical differences between singular/plural (or individual/collective) and inside/outside (or interior/exterior). These quadrants are seen as co-evolving and highly interdependent but at the same time irreducible to each other (see Figure 4 based on Wilber 2000b, 198). 
M. Kleineberg. The Blind Men and the Elephant: Towards an Organization of Epistemic Contexts

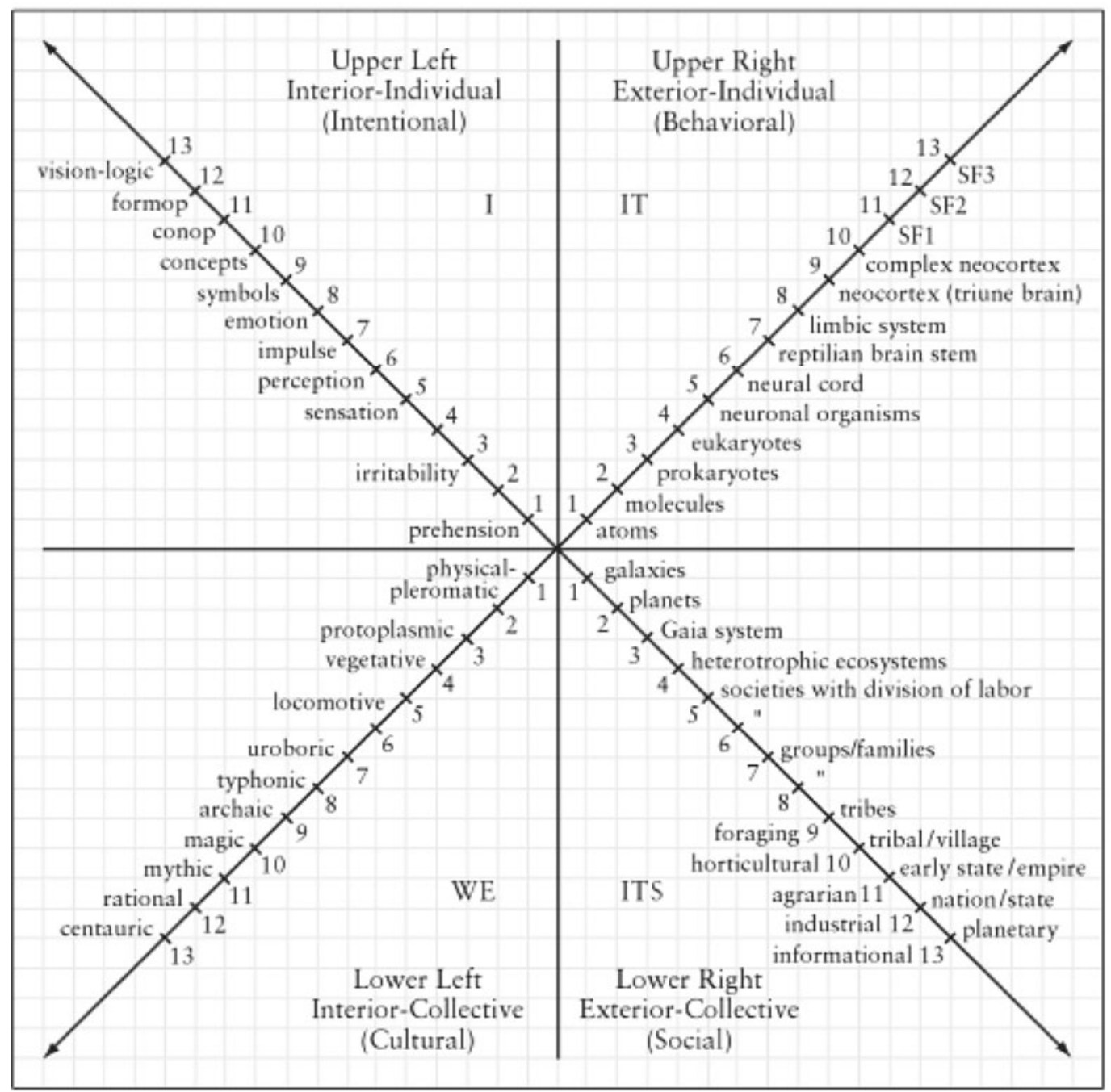

Figure 4. AQAL basic schema

The upper right quadrant ("Behavioral") represents exterior-individual and only in that sense "objective" phenomena described in a third-person-language (e.g., behavior and organism), the upper left quadrant ("Intentional") represents interior-individual and only in that sense "subjective" phenomena described in a first-person-language (e.g., consciousness and knowing), the lower left quadrant ("Cultural") represents interior-collective and only in that sense "intersubjective" phenomena described in a dialogical second-person-language (e.g., worldview and culture), and the lower right quadrant ("Social") represents exterior-collective and only in that sense "interobjective" phenomena described in a third-person-language (e.g., society and environment).

The basic idea of integrative levels is a hierarchy of emergent levels characterized by increasing complexity and integration: "Evolution is indicated not necessarily by increasing size but by increasing depth, or degree of structural organization" (Wilber 2000b, 565). Accordingly, the
AQAL model depicts cosmic evolution from the big bang (origin of ordinates) to today in a series of successive developmental stages.

Following Erich Jantsch, the human brain is the most complex entity known, and the upper right quadrant (exterior-individual) represents some of the main stages or levels of emergence as a sequence from atoms to molecules to cells to more and more complex organisms up to human beings ("SF" stands for "structure function" as a place holder for brain physiological counterparts of complex consciousness evolution, see Feinberg 2011).

According to the principle of co-evolution, mental phenomena like perceptions, emotions, or symbolic and conceptual thinking correspond with neural or physiological states, in other words, consciousness development parallels brain development and is represented in the upper left quadrant (interior-individual). For example, the cognitive competences of fish and amphibians ("neural chord") are limited to simple perceptions, while reptiles ("brain 
stem") possess also impulses and rudimentary emotions; furthermore, lower mammals ("limbic system") and higher mammals ("neocortex") are increasingly able to more complex forms of cognition. Beyond that, human beings can develop linguistic (“concepts"), concreteoperational ("conop"), formal-operational ("formop"), or postformal ("vision-logic") modes of thinking (for a discussion of postformal cognition see Alexander and Langer 1990; Wilber 2000b). In cognitive and comparative psychology, such levels of cognitive competence are typically modeled as developmental stages based on the principle of integrative levels (Campbell and Bickhard 1986; Tobach 1987). Correspondingly, consciousness evolution can be traced back to phylogenesis, although its roots seem to be blurred and obscure.

The principle of panpsychism underlying the integral model maintains that exterior and interior developments are equiprimordial which means to have the same origin in time and to co-evolve from the beginning. In opposition to popular theories of emergent evolution, consciousness phenomena in a broad sense of a first-person-perspective are not supposed to jump suddenly into existence ex nihilo but to develop successively from vague beginnings to forms of increasing complexity and integration (Wilber 2000b). Not only Alfred N. Whitehead concedes a specific form of interiority ("prehension") even to atoms, but Søren Brier (2008, 99), referring to Charles S. Peirce, also argues for panpsychism: "The implication of this is that qualia and 'the inner life' are potentially there from the beginning." Although in strong opposition to present mainstream views, such a notion has always been an underlying theme in the history of Western thought and is put forward by philosophers like Galen Strawson or cognitive scientists like David J. Chalmers even today (Skrbina 2005). Nevertheless, it is not necessary to adopt a panpsychist worldview to apply the framework of integral theory in a fruitful way since the beginning of consciousness evolution could easily be represented in higher stages in the upper left quadrant.

In the lower half of the model, the collective counterparts of exterior and interior phenomena are depicted since evolution is not limited to single entities (microevolution) but also includes systems or societies of these entities (macroevolution) (Jantsch 1980, 75-182). In the lower right quadrant (exterior-collective), the levels of material macroevolution are represented as they correspond with the levels in microevolution. For example, at the level of atoms, the most complex phenomenon in macroevolution is a star as integral part of a galaxy or supergalaxy. Likewise, at the level of molecules, the most complex phenomenon is a planet; at the level of cells, the most complex phenomenon is an autotrophic ecosystem (also known as "Gaia system" coined by Lynn Margulis and
James Lovelock), followed by heterotrophic ecosystems in which, for the first time, organisms metabolize other organisms. Furthermore, collective levels of increasing complexity are represented up to the appearance of human societies, which themselves can develop through different stages from foraging to horticultural and agrarian to industrial and informational societies. According to the principle of integrative levels, each level includes and transcends the lower levels, for example, the existence of an ecosystem depends on the existence of a planet which itself depends on the existence of a star or a galaxy.

Finally, in the lower left quadrant (interior-collective), the levels of intersubjectivity are represented as they manifest in human societies as shared worldviews. In other words, consciousness evolution is an interdependent process related to both microevolution (psychogenesis) and macroevolution (sociogenesis). Habermas (1984, 68) writes:

As is well known, Piaget distinguishes among stages of cognitive development that are characterized not in terms of new contents but in terms of structurally described levels of learning ability. It might be a matter of something similar in the case of the emergence of new structures of worldviews.

The reconstruction of such a long-term development of worldview structures is the main concern of the historicogenetic approach in sociology of knowledge which also leads to stage models following the principle of integrative levels (Piaget 1973; Hallpike 1979; Habermas 1984; Kitchener 1987; Piaget and Garcia 1989; Oesterdiekhoff 1997; Dux 2011; Wenzel 2000; Robinson 2005; Tsou 2006; Bammé 2011).

To what extent we can speak of intersubjectivity at the sub-human levels depends on the chosen starting point of consciousness evolution in general. For example, biosemiotics concedes specific modes of intersubjectivity also to simple organisms and cells (Brier 2008), whereas Whitehead, as quoted by Poli, considers even the atomic level as a "society of minds." The labels of the quadrants (consciousness, behavior, culture, and society) should be taken in the same sense of terminological analogy, since these concepts are obviously anthropocentric, whereas they are meant to embrace all successive levels and merely indicate specific categories: subjective, objective, intersubjective, and interobjective (see Figure 5).

The "quadrants" and "levels" can be considered as the basic schema of the AQAL model. However, in order to locate phenomena even more precisely the integral framework introduces further elements which should at least be mentioned here. Within the level sequence in each quadrant, there are different more or less independent devel- 
M. Kleineberg. The Blind Men and the Elephant: Towards an Organization of Epistemic Contexts

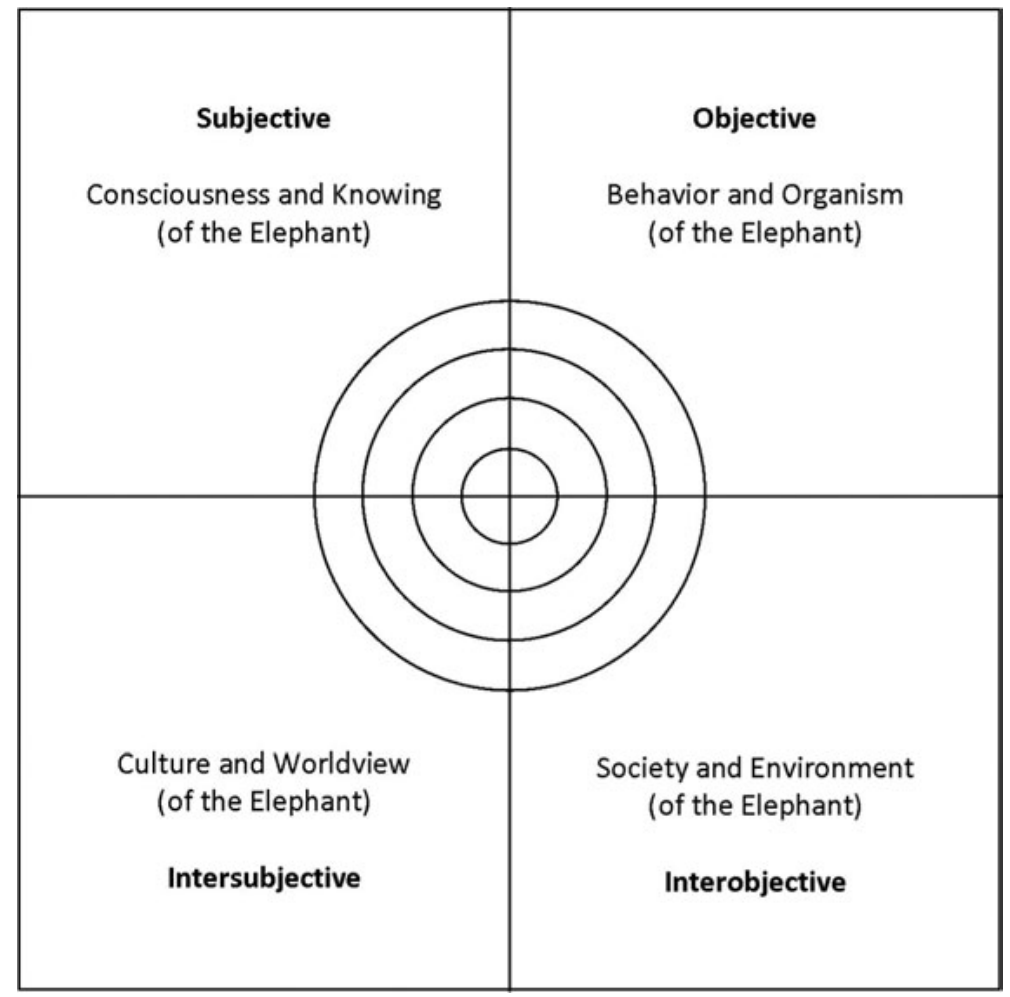

Figure 5. Levels of being (AQAL)

\begin{tabular}{|c|c|c|c|c|c|c|}
\hline & Needham & Feibleman & Hartmann & ILC & Brier & AQAL \\
\hline Atom & \multirow{2}{*}{ Inorganic } & Physical & \multirow{2}{*}{ Material } & \multirow{2}{*}{ Matter } & Physical & \multirow{2}{*}{ Physiosphere } \\
\hline Molecule & & Chemical & & & Chemical & \\
\hline Cell & \multirow{2}{*}{ Biological } & Biological & Organic & Life & Biological & \multirow{2}{*}{ Biosphere } \\
\hline Organism & & Psychological & Psychic & Mind & Psychological & \\
\hline \multirow{2}{*}{$\begin{array}{l}\text { Human } \\
\text { Being }\end{array}$} & \multirow[b]{2}{*}{ Social } & \multirow[b]{2}{*}{ Cultural } & \multirow[b]{2}{*}{ Spiritual } & Society & \multirow[b]{2}{*}{ Linguistic } & \multirow[b]{2}{*}{ Noosphere } \\
\hline & & & & Culture & & \\
\hline
\end{tabular}

Table 1. Level models

opmental "lines" (e.g., in consciousness evolution there are lines of cognitive, moral, ego, or value development) and specific "types" (e.g., feminine or masculine) of such lines, supplemented by temporary "states" (e.g., anger, happiness, flow or peak experiences) (for an introduction see Combs and Esbjörn-Hargens, 2006; Esbjörn-Hargens 2010). Admittedly, Wilber emphasizes that many details have to be completed and that the basic schema of his integral model is "nothing but a simple schematic summary to help further discussion” (Wilber 1997, 72).

In comparison to traditional linear level models such as the ILC's basic schema, the advantages offered by the AQAL ontology based on the principles of co-evolution and panpsychism, although the latter is merely a logical consequence of the former, becomes more apparent (see Table 1).

While in ILC, "matter" is considered as the lowest main level, in AQAL, material phenomena are represented by the right-hand quadrants embracing all levels of complexity from atoms to brains and from galaxies to computers of the information age. Following Pierre Teilhard de Chardin, the main levels in the integral model are termed "physiosphere" (1-2), "biosphere" (3-8), and "noosphere" (9-13), the latter derived from Greek voũc, nous = "mind," "spirit" (Wilber 2000b, 15).

According to integral theory, all quadrants at each level co-evolve. This implies that, first of all, even the lowest inorganic levels of physiosphere contain diffuse forms of 


\begin{tabular}{|l|c|c|c|}
\hline & $\begin{array}{c}\text { Objective/ } \\
\text { Interobjective }\end{array}$ & Intersubjective & Subjective \\
\hline Plato & The Truth & The Good & The Beautiful \\
\hline Immanuel Kant & Pure Reason & Practical Reason & Judgment \\
\hline Max Weber & Science & Moral & Selbst-Welt \\
\hline Martin Heidegger & Um-Welt & Mit-Welt & World 2 \\
\hline Karl Popper & World 1 & World 3 & Truthfulness \\
\hline Jürgen Habermas & Truth & Rightness & Inner World \\
\hline Günter Dux & Physical World & Social World & Spirit \\
\hline Søren Brier & Third-Person-Perspective & $\begin{array}{c}\text { Second-Person- } \\
\text { Perspective }\end{array}$ & First-Person-Perspective \\
\hline Ken Wilber & Nature & & \\
\hline
\end{tabular}

Table 2. Value spheres and validity claims of knowledge

interiority or qualia, and, secondly, that there is a clear distinction between micro or individual phenomena (e.g., atom, molecule) and macro or collective phenomena (e.g., star, planet). In opposition to ILC, in the AQAL's biosphere the areas of "life" and "mind" are not considered as separate and subsequent levels, but as two co-evolving areas of phenomena (right hand versus left hand quadrants) both succeeding the same general level sequence. As all levels, biosphere makes a distinction between individual phenomena (e.g., organism) and collective phenomena (e.g., ecosystem). Finally, ILC's distinction between a material "society" and an immaterial "culture" as subsequent linear levels is replaced by co-evolving quadrants (lower right and lower left) in AQAL's noosphere. The noosphere is also the place to locate technical or cultural artifacts and documents since their historical appearance depends on the human mind and its developmental stages (for pioneering works of a developmental approach to the organization of cultural artifacts see Goldmann 1975; Gebser 1985; Thompson 1996; Combs 2005).

In opposition to traditional linear level models, the coevolutionary AQAL model offers for the first time a consistent concept of integrative levels in terms of both the integrative principle as well as the chronological principle. Accordingly, the integral model provides a conclusive level concept even for social, cultural, and mental phenomena which seem to be treated more intuitive and unmethodical in previous phenomena-based KOS’s (Huckaby 1972; Spiteri 1995; Gnoli and Poli 2004). For example, from the perspective of integral theory, Poli's areas "history," "art," "law," and "economy" in Figure 4 are not considered as genuine levels of being but as specific developmental lines which itself can evolve through different levels of complexity.

Furthermore, the differentiation in four quadrants reflects the "differentiation of three values spheres" (Habermas 1984, 164), which can be seen as a main achievement of modernity, also denoted as "knowledge areas" (Brier 2000, 444) or "The Big Three" (Wilber 2000b, 149). By those means, some fundamental context references are made visible which seem to be rather marginalized in $\mathrm{KO}$ theory (see Table 2).

In conclusion, the traditional organizing principle "levels of being" could benefit from the differentiation in coevolving areas of phenomena in a considerable way. From the perspective of integral theory, one of the most important challenges for knowledge organization is the notion of developmental levels of interiority which are supposed for both levels of consciousness in psychogenesis (interior-individual) and levels of worldviews in sociogenesis (interior-collective). Such a novel organizing principle might be termed "levels of knowing" (Campbell and Bickhard 1986, 1), which can also be labeled as "levels of representation" (Gnoli and Poli 2004), "levels of description" or "levels of interpretation" (Poli 2001, 261-62), "levels of abstraction" (Piaget and Garcia 1989, 264), or "levels of consciousness" (Wilber 2000b, 214). But this refers already to the epistemological dimension of knowledge which should be treated in the next section.

According to integral theory, however, these two dimensions are inextricably interwoven: "In my view, the basic structures in the Great Nest [= "levels of reality," M.K.] are simultaneously levels of both knowing and being, epistemology and ontology" (Wilber 2000a, 236). 
Likewise, the cybersemiotic approach is fundamentally based on such an integrative level model, considered as "combined ontology and epistemology, conceptualized as ... levels of existence and knowing” (Brier 2008, 389).

In other words, there are not only different levels of being but at the same time different levels of knowing the being. Admittedly, the "modernist" approaches to knowledge organization consider the epistemological dimension as secondary when maintaining a primacy of the ontological dimension as it is programmatically expressed in the Integrative Levels Classification project: "Its unities of classification are phenomena, considered as neutral objects of knowledge, independent from any approach or viewpoint by which they can be treated" (ISKO Italy 2007, 8; see also Gnoli and Poli 2004; Gnoli 2012). In this view, the points of reference are pre-given ontic structures which implicate that the validity of knowledge is seen as completely independent from the contextuality of knowledge production. In recent theory of knowledge as well as in the philosophy of science such a view is seen as metaphysical thinking and, therefore, hopelessly outdated as pointed out by Habermas $(1992,49)$ :

Such internal connections between genesis and validity have been uncovered by pragmatism from Peirce to Quine, by philosophical hermeneutics from Dilthey to Gadamer, and also by Scheler's sociology of knowledge, Husserl's analysis of the lifeworld, the anthropology from Merleau-Ponty to Apel, and postempirist theory of science since Kuhn.

Conclusively, neutral or context-independent knowledge simply does not exist. For that reason, each phenomenon has to be considered in its own context of discovery (or more precisely: context of genesis). As a consequence, for a phenomena-based KOS, it is mandatory to organize epistemic contexts in a systematic way, as will be sketched out in the next two sections.

\subsection{The WHO of knowledge: epistemology}

If the elephant is a metaphor for reality, then the blind men do not only represent the access points to an object under investigation but also indicate the fact that knowledge is always knowledge by someone. In other words, even if the seven blind men each examine the elephant's trunk the result could be seven completely incommensurable descriptions. This refers to the epistemological question for the WHO of knowledge.

Epistemology (Greek: غ่ $ぇ \sigma \tau \dot{\eta} \mu \eta$, epistéme = "cognition," "knowledge") is the study of knowledge and how it is acquired and influenced. According to Hjørland and Hartel (2003, 242), epistemological theories are typically concerned with:

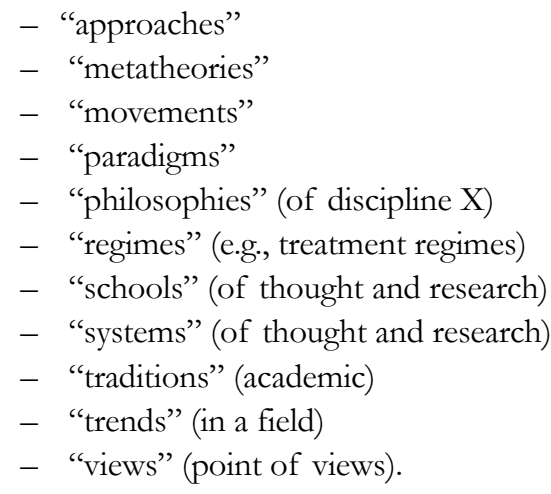

According to the weak interpretation of the parable by the "modernists," there would be only one valid representation of reality, while all the others would be biased, incomplete, or deluded in some way. But such an assumption implicates the possibility to have a view from nowhere or a God's eye perspective which allows to see reality how it "really" or "in itself" is (realism). In contrast, the strong interpretation by the "postmodernists" denies the existence of such a privileged point of view arguing for a plurality of equally valid viewpoints since there is no place from which to compare divergent constructions of reality in an unbiased way (anti-realism). A mediating role between these extreme positions could be taken by a metatheoretical standpoint which might be termed "constructive realism.” Dux $(2011,148)$ writes:

Let us note that each and every organization of life is only capable of forming in an autonomous universe by keeping this autonomy in mind. If one takes this into account, a postulate results regarding the constructivism of human knowledge that can hardly be negated: this constructivism must be able to integrate reality into its constructs in such a way that reality-based knowledge is gained... . By taking this turn at least provisionally, the theory of knowledge would assume a position compatible to what I term constructive realism or realistic constructivism.

In combining epistemology and ontology, this theory of knowledge seeks to integrate both the undeniable constructivism of human knowledge as well as its capability to reflect reality which is seen as partially independent from a human observer. In other words, neither the premise of pre-given ontic structures nor the premise of arbitrary epistemic constructions of reality are required, two extreme positions also known as the "myth of the given" invented by Wilfried Sellars and the "myth of the framework" coined by Karl R. Popper (Esbjörn-Hargens and Zimmerman 2009, 563).

Thus, an integration of the "modernist" and "postmodernist" approaches requires, on the one hand, a de- 
fense of a realistic standpoint since there is a resistant outside world partially independent from human beings as a point of reference or corrective for learning processes including for our social constructions of reality (Bickhard 1993). On the other hand, we have to recognize that the knowing subject is always an integral part of reality which implies that there is no view from nowhere (external realism), but only perspectives embedded in various contexts (internal realism).

Following Hilary Putnam, George Lakoff, and Mark Johnson, as well as Martin Heidegger's notion of being-inthe-world, Brier $(2008,145)$ comes also to the conclusion: "Internal realism is the only realism we can have." In this respect, his distinction between "objective reality," which is rejected, versus "outside reality," which is accepted, seems to be crucial (Brier 2008, 233). Therefore, the situated lifeworld of the knower has to be taken into account. Habermas (2009, 204; my translation) writes:

Anticipatory, the lifeworld can be described as the non-exceedable, only intuitively accompanying horizon of experience and as the fundamental, not consciously present background of a personal, historically situated, corporally embodied, and communicatively socialized everyday existence.

Referring to Habermas and Merleau-Ponty, Brier analyses the contextuality of human knowledge in some more detail. Brier's (2008, 360-62) results replicate the fourfold distinctions of the integral model (for further convergence between cybersemiotics and integral theory see Esbjörn-Hargens and Zimmerman 2009, 555):

But I do contend that the foundation for understanding the sciences, social sciences, arts, humanities, and practical sciences, as well as philosophy and other systematic searches for meaningful, justified, and true public knowledge, must begin with the prerequisite that human beings are:

1) embodied and biologically situated - our body is the principal system for the manifestation of life and cognition;

2) conscious and intentionally situated - consciousness is the source of an inner life of cognition, volition, feeling, and perceptual qualities (qualia);

3) meaning-situated in cultural practice - that is, through language in a social and cultural activity with a network of other living, linguistic, conscious systems; and

4) environmentally situated - in a nature or a universe that is partly independent of our perception and being.
Each of these four worlds demands its own type of narrative.

For a systematic organization of epistemic contexts, these "four worlds" or quadrants identified by Brier and Wilber offer a reasonable point of departure: behavior and organism (objective), consciousness and knowing (subjective), culture and worldview (intersubjective), society and environment (interobjective).

Since both the known and the knower have to be seen as integral parts of reality, the AQAL model enables not only to locate the known objects in the ontological dimension but equally the knowing subjects in the epistemological dimension, in our case the prerequisites of the blind men (see Figure 6).

The integral model visualizes the interdependent relations between four multi-leveled quadrants seen as contextual main areas in order to avoid the pitfalls of monocausal explanations of human knowledge, how they are occasionally postulated by reductionisms such as physicalism (objective), psychologism (subjective), sociologism (intersubjective), or even holism (interobjective) (EsbjörnHargens and Zimmerman 2009).

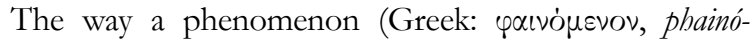
menon = "that which appears," "occurrence") is perceived and described depends on a complex context which as a non-exceedable horizon and pre-understanding influences our theoretical and metatheoretical background assumption as Hjørland emphasizes in a debate with Szostak (Hjørland and Pedersen 2005; Hjørland 2008, 2009, 2010; Szostak 2008a, 2008b, 2010). Hjørland (2008, 337-38) writes:

However, what Szostak ignores is that different theories "see" different phenomena in the world and uses different methods as well. Szostak seems to suggest that there is a neutral position from which the world can be observed objectively. I believe this is wrong. In the philosophy of science have an "interpretive turn" taken place and the hermeneutic circle is now acknowledged as a fundamental condition. This turn implies that all interpretations are circular, indetermined, and perspectival. This is also the case when describing and classifiying phenomena.

Therefore, integral theory considers the phenomena classified in the AQAL basic schema not as pre-given ontic entities but as "largely-agreed-upon orienting generalizations from the various branches of knowledge" (Wilber $2000 \mathrm{~b}, 5)$. At this juncture, the denominations of the AQAL main classes are mostly adopted from other theorists, in particular, Erich Jantsch, Gerhard Lenski, Jean Piaget, Erich Neumann, Jean Gebser, Erik Erikson, and Alfred N. Whitehead. 


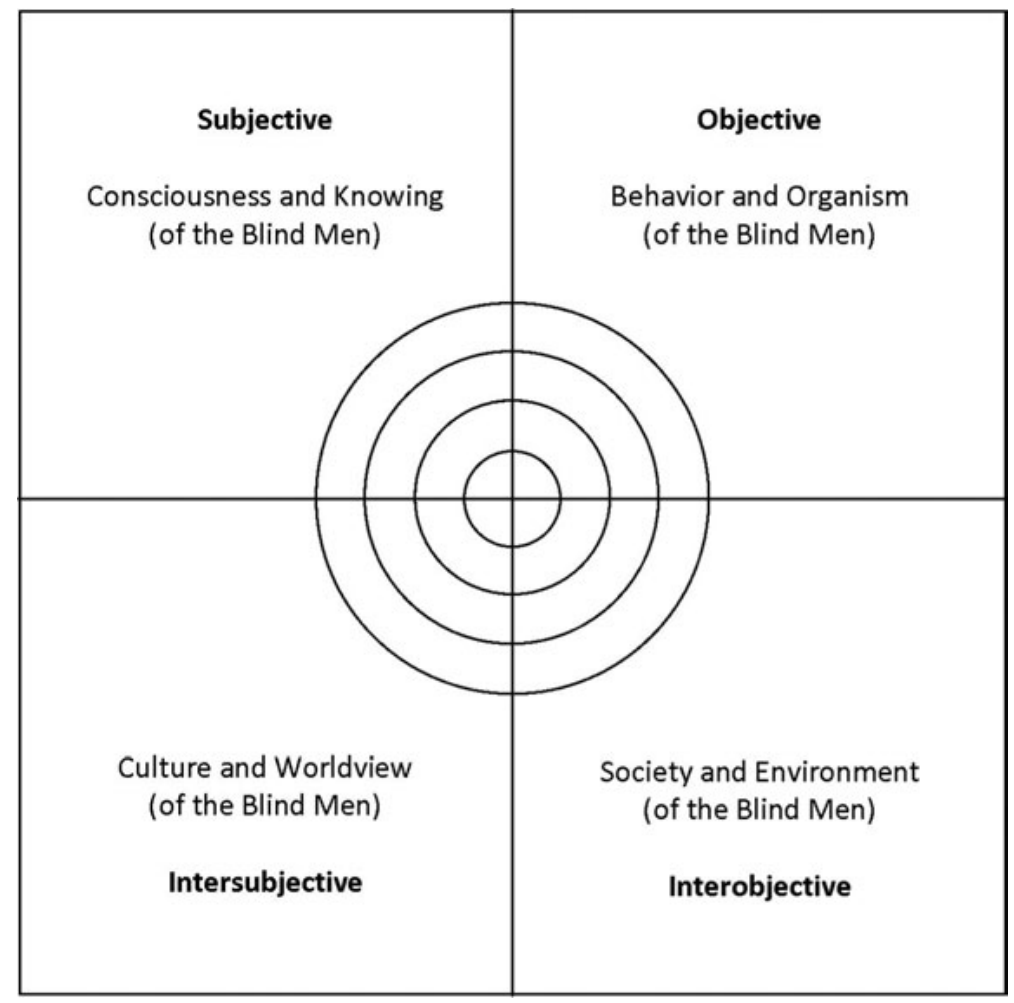

Figure 6. Levels of knowing (AQAL)

In other words, phenomena should not be seen as objective and neutral representations of reality but as timedependent (re-)constructions which are in potential need of revision. The present scientific theories are the point of reference but understood as manifestations of historically situated worldviews. Therefore, even the most valid scientific knowledge is considered as potentially obsolete in order to avoid ahistorical thinking: "In this way, ontological theories change as conceptual and social structures ... change" (Hjørland and Hartel 2003, 24).

As a consequence, the common criticism raised by Elaine Svenonius (2004) that the concept of integrative levels is necessarily based on a referential or picture theory of meaning does not hold since even a contextual or instrumental theory of meaning is compatible with the notion of stable patterns in nature such as nested hierarchies. In this paper, however, it is argued for a combination of both as it is proposed by integral theory or cybersemiotics.

But even a differentiation of the epistemological dimension into quadrants as areas of contexts seems not to be sufficient to face the challenge of relativism which is often concluded from perspectivism in claiming that each perspective is equally correct and valid: "It would be difficult to argue that only one of the classifications is true representation of the knowledge and others are not true - or that one is more true than the others" (Mai 2004, 41). Therefore, the main task for any transdisciplinary approach to $\mathrm{KO}$ is to show how the manifold domain-specific perspectives are interrelated in order to provide a point of departure for mutual understanding, concept translation, and perspective taking as proclaimed, for example, in the León Manifesto: "the new KOS should allow users to shift from one perspective or viewpoint to another" (ISKO Italy 2007, 6; see also Szostak 2007, 76; Kaipainen and Hautamäki 2011, 509).

The "modern contextualists" (Dervin 2003, 130), in claiming a primacy of ontology, tend to a reification of contexts, treating them merely as aspects or facets of a given phenomenon, whether it is an elephant or an ordinary pen as in an analog example. Gnoli and Poli (2004, 152) write:

All these different descriptions are correct: each of them expresses a facet of the object. Yet they are all descriptions of the same object. Hence, one of the main tasks of information science is to find ways to integrate different descriptions of the same object.

But such a view marginalizes the differences of contradicting perspectives, and, even more important, relies fundamentally on the metatheoretical assumptions of external realism which has been rejected by most theorists in the philosophy of science for decades. In separating the known object from the knowing subject, such a weak no- 
tion of context mistakes the constitutive role of the epistemological dimension with regard to human knowledge. The conclusion: though the "modernist" approaches to $\mathrm{KO}$ maintain a universal scope, these theories are not able to adequately implement perspectivism and contextualism.

In contrast, the "postmodern contextualists" (Dervin 2003,130 ), in claiming a primacy of epistemology, tend to an absolutization of contexts in overemphasizing the arbitrariness of knowledge construction. In constructivism, phenomena are legitimately seen as products of the epistemic activity of human beings, in the way that the blind men investigating the elephant give not merely different descriptions but "see" different phenomena. In other words, the elephant in itself or a neutral description of the elephant does simply not exist since there is always an observer co-constructing the object of interest. But postmodernism at least in its stronger versions as stereotypically described by Mai (1999) or Szostak (2007) commonly concludes that epistemic pluralism implies epistemic relativism. Therefore, most "postmodernists" insist that the scope of any KOS should be limited to specific "knowledge-domains" (Hjørland and Hartel 2003, 242) seen as practice and discourse communities which constitute their own forms of life, language-games, and worldviews. In other words, a context-transcending such as a transdisciplinary or universal KOS is judged as unfeasible from the beginning (Jacob 2000; Mai 2004; Hjørland 2008). Such a view seems to underestimate the reality-based aspects of human knowledge in relying on the metatheoretical assumptions of anti-realism. Obviously, such an absolutist constructivism possesses no criteria to make the divergent social constructions commensurable since the grasp on reality is completely lost (Bickhard 1993). In rejecting a partially human-independent reality, such a strong notion of context mistakes the constitutive role of the ontological dimension with regard to human knowledge, in particular as reference point for learning processes as well as for cross-contextual translations. Wilber (2000b, 629) writes:

We can translate languages because, even if all contexts are situated, a great number of contexts are similarly situated across cultures. "Context" does not automatically mean "relative" or "incommensurable."

The conclusion: Though the "postmodernist" approaches to $\mathrm{KO}$ take perspectivism and contextualism into account, these theories are not well equipped to defend a contexttranscending not to mention universal scope of a KOS. Both approaches do not appear to be sufficient for an adequate transdisciplinary integration of knowledge. Thus, the point of departure for an alternative approach should be a metatheoretical position based on a combina- tion of both ontology and epistemology which would implicate a multi-dimensional knowledge concept (Brier 2008, 205-06). Onion and Orange $(2002,5)$ write:

Knowledge is a transient state at the confluence of what is known, how it is known (knowing), and who knows it (knower).

In difference to the "modernist" and "postmodernist" positions rather stereotypically contrasted in this paper, some main protagonists in recent discourse represent much more balanced points of view. On the one hand, the interdisciplinary approach proposed by Szostak (2007) argues also for a third alternative, acknowledging that "human perceptions of reality are to some extent constructed and to some extent constrained by external reality" (Szostak 2007, 46). Referring to Habermas, Szostak even attacks epistemic relativism since "scholars engaged in an open honest conversation can aspire to increased understanding" (Szostak 2007, 41). On the other hand, Hjørland (2008) emphasizes that to accept perspectivism does not mean to accept anti-realism: "I do not believe this leads to skepticism or antirealismus, because some theories do a better job than others" (Hjørland 2008, 338). But neither, however, comes to the self-evident conclusion that human knowledge as the confluence of the known and the knower has to be seen from a developmental perspective how it is offered, for example, by the historicogenetic approach in the sociology of knowledge (Dux 2011) or by integral theory (Wilber 2000b). EsbjörnHargens and Zimmerman (2009, 8) write:

During maturation the human worldspace [= "levels of knowing", M.K.] expands and deepens enormously in many different ways. Because a more expansive and inclusive interior allows a more comprehensive worldspace to emerge, some assertions made about a given phenomenon are more comprehensive, and thus have greater validity, than other claims. Hence, integral perspectivalism is not equivalent to relativism. We do not assert that all perspectives are equal. Some truths are more comprehensive than others.

In ontogenesis, as well as in phylogenesis (or more precisely: in historiogenesis), reconstructive sciences such as cognitive psychology or cognitive anthropology are able to identify different developmental stages of cognitive competence or levels of knowing from which one and the same object can be seen as different phenomena. Again, the elephant parable can give us an illustration: within a premodern magico-animistic worldview structure (preoperational cognition) the elephant might appear as a to- 
M. Kleineberg. The Blind Men and the Elephant: Towards an Organization of Epistemic Contexts

temistic animal ghost, whereas within a mythic-metaphysical worldview structure (concrete-operational cognition) the elephant would rather be recognized as one creature in the middle of a divine creation. Likewise, within a modern rational-scientific worldview structure (formal-operational cognition) the elephant would be considered as a biological organism and product of a natural evolution, whereas within a postmodern pluralistic worldview structure (postformal cognition) the elephant is seen as an integral part of complex ecosystems and as an autopoietic form of life which constitutes its own species-typical construction of reality (for a detailed reconstruction of worldview structures see Habermas 1984, 43-74; Wilber 2000b, 210-261; Bammé 2011, 73-250; Dux 2011, 257-374).

At least, such a strongly simplified example indicates the discontinuity between the levels of knowing, which is why metatheoretical approaches based on a combined ontology and epistemology label such a view as "multi-stage realism" (Neuhäuser 2003, 178; my translation, M.K.) or "genetic ontology" (Fetz 1982, my translation, M.K.) in analogy to the well-known genetic epistemology proposed by Piaget. Although the chronologically later and more complex levels of knowing include the cognitive competencies of its precursors, none of these stages should be ahistorically regarded as the ultimate level of knowing since development is an open process.

In other words, the "postmodernists" would legitimately emphasize that there simply is no elephant "initself" but merely perspectives. Following cybersemiotics and integral theory, elephants as well as other phenomena do indeed exist independently from human observers but the crucial point is they do not exist independently from any observer at all. An elephant seen by a conspecific, respectively a cell, a molecule or even an atom seen by the likes of them, appears as a phenomenon, but as a significantly different one as for a human being whether a tribal cave painter or a scientist socialized in a postmodern information society. Certain phenomena (e.g., an elephant as molecular-biological phenotype of an evolutionary developed DNA sequence) only "appear" within a specific level of knowing, which is why these phenomena literally depend on knowing subjects with an adequate cognitive competence: "Real objects are not seen from a perspective-they are within that perspective" (Esbjörn-Hargens and Zimmerman 2009, 179). If one follows the premise of the equiprimordiality of ontic and epistemic development, then both have to be seen as an inextricable unity similar to the well-known equivalence concepts of "spacetime" or "energy-matter" (for the ontological-epistemological concept of "dimension-perspective" see EsbjörnHargens and Zimmerman 2009, 58). According to this view, there is no being without knowing, no knowledge without a knower, and no phenomenon without a level of knowing in which it appears (for the concept of "phenomenological space" or "worldspace" see Wilber 2000b, 568-69).

In each case, a reconstruction of the structural development of human worldviews described as hierarchically emerging integrative levels of knowing seems to be promising to enrich theory-building in $\mathrm{KO}$ research. Here, the crucial point is the distinction between the content of worldviews (cultural variant surface structures) and the underlying modes of thinking or types of rationality (cultural invariant sequence of deep structures) (Habermas 1984; Dux 2011; Wilber 2000b).

According to the principle of integrative levels, the higher and more complex levels of knowing integrate and transcend the lower levels. Habermas $(1984,68)$ writes:

With the transition to a new stage the interpretations of the superseded stage are, no matter what their content, categorically devalued. It is not this or that reason, but the kind of reason, which is no longer convincing... . These devaluative shifts appear to be connected with socio-evolutionary transitions to new levels of learning, with which the conditions of possible learning processes in the dimensions of objectivating thought, moral-practical insight, and aesthetic-expressive capacity are altered.

From this perspective, even the difference between "modernism" and "postmodernism" appears as a transition between different deep structures implicating a "devaluative shift," which categorically devalues the arguments proposed by a mode of thinking not reflecting the constitutive role of the knowing subject (for a discussion of modernity/postmodernity informed by developmental theory see Dux 2011; Wilber 2000a, 2000b; Bammé 2011).

This is exactly the reason why the theoretical foundations of a phenomena-based $\mathrm{KO}$ as it is sketched in the León Manifesto would not be able to convince anybody from the "postmodernist" camp. In a similar analysis, Jens-Erik Mai identifies the "shift from classification-asontology, in which everything is defined as it is, to a more contemporary notion of classification-as-epistemology, in which everything is interpreted as it could be" (Mai 2011, 711) as the transition from modern to late modern or postmodern approaches. But a profound criticism of "modernism" in combination with an equivalence thesis claiming that all perspectives are equally correct and valid would involve itself in a performative contradiction (Szostak 2007, 77; Esbjörn-Hargens and Zimmerman 2009, 63-64). This could be avoided in adopting the nonrelativistic concept of levels of knowing as proposed in this paper. In this regard, Kleineberg (2012) identifies a further and even more elementary stage in the history of 
classificatory cognition which one might add to the "postmodernist" and "modernist" approaches to KO and label as "premodernist." From such a developmental view based on a historico-genetic reconstruction of worldview structures, the question will be inevitably raised how a future approach to $\mathrm{KO}$ would look like. A preliminary answer is offered by Wilber (2000b, IX):

But once consciousness evolves from formal to postformal-and thus evolves from universal formalism to pluralistic relativism-these multiple contexts and pluralistic tapestries come jumping to the fore, and postmodernism has spent much of the last two decades attempting to deconstruct the rigid hierarchies, formalisms, and oppressive schemes that are inherent in preformal-to-formal stages of consciousness evolution. But pluralistic relativism is not itself the highest stage of development ... . Pluralistic relativism gives way to universal integralism. Where pluralism frees the many different voices and multiple contexts, universal integralism begins to bring them together into a harmonized chorus.

In this somewhat ambitious attempt to a contexttranscending integration of knowledge, the universal scope of "modernism" ("universal formalism") should not be confused with the universal scope of, if you will, "postpostmodernism" ("universal integralism"); similar to the distinction between "world formula thinking" (Brier 2008, 274) versus "transdisciplinary integration" (Brier 2008, 143). The latter can also be described as an "alliance between perspectivism and realism" (Brier 2008, 233) which means that the epistemological dimension is consequently seen as an integral part of reality. In this view, the "postmodernist" assumption of a "multiplicity of co-existing universes" (Jacob 2000, 19) is taken for granted, although, the sum total of the divergent perspectives is once again seen as a unity, respectively called reality. In order to distinguish such a combined ontological and epistemological concept of reality from the more common view of the merely physical "cosmos," Wilber re-introduces the ancient term "Kosmos" (Wilber 2000b, 45) indicating a more holistic view and rejecting what he calls "flatland ontology" (Wilber 2000b, S. 695) also known as "desert ontology" (Campbell and Bickhard 1986, 23).

Accordingly, an adequate description of a known object would be an integration of the manifold mutually contradictory perspectives. Esbjörn-Hargens and Zimmerman (2009, 565) write: "In one sense, integral knowledge of a phenomenon is the totality of interpretative perspectives taken on it by investigators using reliable methods." The crucial question is how and to what extent we are able to organize the perspectival and contextual pluralism which are embedded in human knowledge without falling prey to epistemic relativism. Szostak (2007, 76) writes: "The basic tenet of postmodernism is that scholars cannot rationally choose among competing perspectives: Only by showing that it is possible to integrate across different perspectives can postmodernism be transcended."

In this regard, the concept of levels of knowing how it is developed, in particular, in integral theory offers a promising organizing principle. In contrast to relativism, this view argues that within the history of science (or more precisely: the history of knowledge) several discontinuities occur, but at the same time we are able to reconstruct an overarching coherence within the long-term development of human cognition (Habermas 1984; Lerner and Kauffman 1985; Bickhard 1993; Oesterdiekhoff 1997; Dux 2011; Wenzel 2000; Wilber 2000b; Robinson 2004; Quilley 2010; Bammé 2011). Piaget and Garcia (1989, 275) write: "in the case where one cognitive structure gets replaced by another, larger one, the old structure becomes integrated within the new one, which permits the continuity of knowledge."

In opposition to Thomas S. Kuhn's famous thesis of incommensurability between subsequent paradigms, Piaget and Garcia (1989, 252) make a distinction between "social paradigm" versus "epistemic paradigm," whereupon only the latter is able to identify and interrelate divergent scientific perspectives in terms of "lower level theory" versus "higher level theory" (Piaget and Garcia 1989, 264-65) in a non-relativistic way (Kitchener 1987; Tsou 2006).

In analogy to traditional subject indexing, the attempt to classify knowledge by taken perspectives or points of view

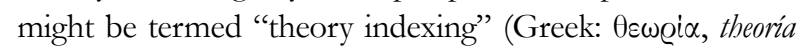
= "a looking at," "viewing") or even more comprehensive "viewpoint indexing." This proposed supplement to indexing theory is to a lesser extent seen as an indexing of single scientific theories but to a higher degree as indexing of more basic metatheoretical assumptions and most important of levels of knowing how they manifest themselves in discourse-specific language-games and worldviews: "The challenge for the indexer is to interpret the world picture ... embedded in the document" (Mai 1999, 554).

Epistemic contexts, however, are not limited to the viewpoints or perspectives (theory) but also include the methods (praxis) applied by the knowing subjects. For this reason, both of them could be subsumed to the epistemological dimension; however, in this paper it will be emphasized that phenomena are always the result of applied methods. In opposition to the weak interpretation that methods are seen as merely means to discover an objectively given reality, the strong interpretation will be adopted that, in fact, methods co-construct the phenomena under investigation (Jacob 2000; Hjørland 2008). Furthermore, an intersubjective validation of human knowl- 
edge requires that other researchers are able to comprehend and reproduce the applied methods. Therefore, for a transdisciplinary approach to KO it seems to be appropriate to consider the methodological dimension of knowledge in its own terms.

\subsection{The HOW of knowledge: methodology}

If the elephant is a metaphor for reality, then the divergent descriptions depend not only on the aspect of the known object (WHAT) or on the perspective of the knowing subject (WHO), but equally important on the method applied (HOW). In other words, even if the seven blind men all investigate the elephant's trunk and even if they all share a similar pre-understanding, a common worldview and a set of language-games, the result could be seven completely incommensurable descriptions again.

In particular, Szostak (2003) argues that scientific documents should not only be classified by subject but also by the theories and methods applied by scholars in order to enhance interdisciplinary knowledge transfer. But while theories tend to change over time and new theories emerge in a rather unmanageable way, methods do not. According to Szostak $(2003,26)$, there is a fair amount of fundamental and more or less well-defined methods which provide a foundation of what one might term "method indexing":

There are, broadly speaking, some twelve distinct methods employed by scholars (often in combination):

- experiments (including natural or quasiexperiments)

- surveys

- interviews

- mathematical models (and simulations)

- statistical analysis (often, but far from always, associated with models), including secondary (that is, collected by others) data analysis

- ethnographic/observational analysis (some would distinguish "interactual" analysis in which the investigator interacts with those under observation)

- experience/intuition (some would treat this as an important subset of observational analysis, since we are in effect "observing" ourselves here)

- textual (content, discourse) analysis

- classification (including evolutionary analysis)

- mapmaking

- hermeneutics/semiotics (the study of symbols and their meaning)

- physical traces (as in archaeology)
- some would treat "evaluation" of programs as distinct, though it can be seen as a combination of some of the above methods. Similar arguments can be made with respect to "demography," case study, feminism, and perhaps also hermeneutics. Certainly, "case studies" involve the use of one or more of the above methods.

This list includes quantitative (knowledge by description) and qualitative (knowledge by acquaintance) methods as well as analytical tools with regard to methodological individualism (elements) and methodological collectivism (systems). In this respect, such a methodological pluralism seems to be appropriate to cover all three value spheres and its distinct validity claims. But a mere list of methods, however, does neither describe how these practices are related nor how to combine them in a meaningful way as an added value for multi-, inter- or transdisciplinary research (for terminology, see Klein 1990, 55-73). Furthermore, the focus seems to be narrowed to scientific knowledge which would limit a future method indexing only to a fraction of the whole cultural heritage (for the complementary concept of "folk method," see Esbjörn-Hargens and Zimmerman 2009, 66).

The AQAL model, already applied to the ontological and epistemological dimensions, provides a framework to systematize the methodological dimension as well. In this regard, Szostak's list of methods which could indeed be analyzed in more detail will be categorized into more general "methodological families" (Esbjörn-Hargens 2006, 88). The concept of methodology (Greek: $\mu$ \&̇odos, methodos = "a following after," "way of teaching or going") is widely used as synonym to "method" and will be adopted to denote the way someone has to follow in order to access the phenomena under investigation: "Each methodology discloses an aspect of reality that other methods cannot” (Esbjörn-Hargens 2006, 87).

The AQAL model locates the qualitative methodologies within the left hand quadrants and the quantitative methodologies within the right hand quadrants. In addition, the methodological individualism is represented in the upper quadrants and the methodological collectivism in the lower quadrants. Furthermore, within each quadrant a distinction is made between a direct perspective (inside) and an indirect perspective (outside). As a result, there are eight well-defined zones or methodological families which are irreducible to each other and interrelated in a complement way. As an organizing principle, this systematization is called "Integral Methodological Pluralism (IMP)" (Esbjörn-Hargens 2006, 84). The denotations given to the zones are merely general labels which each seek to integrate a manifold of zone-specific methods and techniques (see Figure 7 based on Esbjörn-Hargens 2006, 88): 


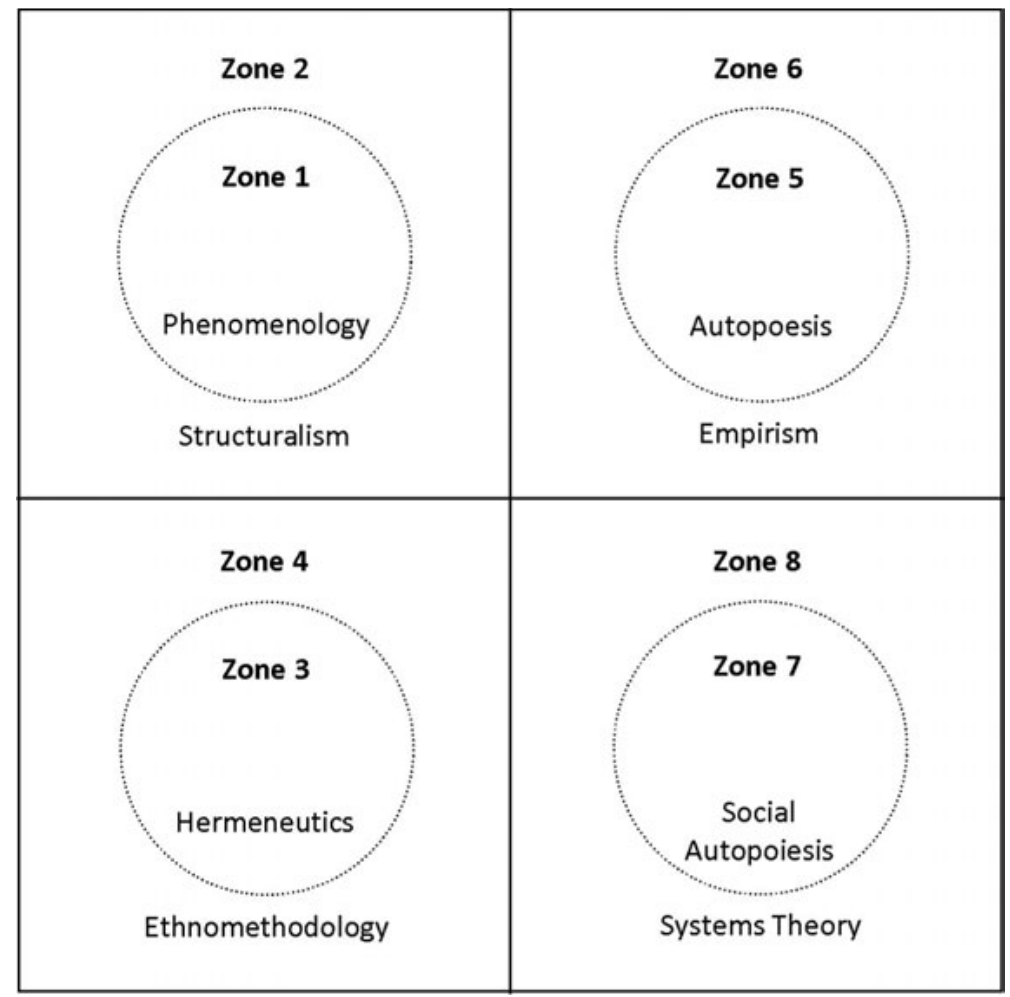

Figure 7. Integral methodological pluralism (AQAL)

Esbjörn-Hargens $(2006,86)$ writes:

In short, IMP is a collection of practices and injunctions guided by the intuition that "Everyone is right!" and each practice or injunction enacts and therefore discloses a different reality. As a result, Wilber proposes three principles that secure a position in reality for all perspectives: nonexclusion (acceptance of truth claims that pass the validity tests for their own paradigms in their respective fields); enfoldment (some sets of practice are more inclusive, holistic, comprehensive than others); enactment (phenomena disclosed by various types of inquiry will be different depending in large part on the quadrants, levels, lines, states, types, and bodies of the researcher used to access the phenomena).

In more detail, subjective phenomena (interior-individual) such as emotions, thoughts, or qualia in general are accessible either directly from a first-person-perspective, or indirectly from a third-person-perspective how it is taken by a therapist with respect to a patient or by a zookeeper with respect to an elephant. In the former case, phenomenological methodologies are applied such as introspection ("experience," "intuition"), in the latter case rather structuralist methodologies, for example in cognitive psychology, are applied ("surveys," "interviews," "observational analysis").
Likewise, intersubjective phenomena (interior-collective) such as cultural backgrounds, shared language-games, values or worldviews are accessible either directly from a participant's perspective ("hermeneutics"), or indirectly from a more distant observer's perspective ("ethnographic analysis"). The fact that intersubjective phenomena can also be studied in pre-human areas is documented by new research developments, particularly, in zoohermeneutics and biosemiotics (Brier 2008; Esbjörn-Hargens and Zimmerman 2009).

On the other side, objective phenomena (exteriorindividual) such as an organism of a human being or an elephant are accessible either directly from an internal organism's perspective, or indirectly from an external perspective. The latter is nothing else, but the most common scientific practice of empirism such as counting, measuring, or weighing ("experiments"). In contrast, the former methodology labeled as autopoiesis is one of the less selfexplanatory techniques and one of the latest developed in the history of science. This methodological zone is also not mentioned on Szostak's list. Developed by Chilean biologists Humberto Maturana and Francis Varela, autopoiesis seek to examine the biological level of epistemology. The basic idea is to reconstruct how an organism registers its environment, although, not in terms of qualia (interiorindividual) but in terms of third-person-language, for example, as a description of how the organism's materiality 
(sensory organs, messengers, neural impulses, etc.) constitutes its cognition of what is. Such a reconstruction seems to be promising to learn something about the organism's ability to construct its own conspecific reality. Brier (2008, 194) writes:

The main achievement of Maturana and Varela ... is that they have conceptualized the basic limits of living and knowing - namely the autopoietic system and have shown that there is a basic connection between living and knowing: To live is to know!

Finally, interobjective phenomena (exterior-collective) such as cybernetic systems, biological ecosystems, or human societies are accessible either directly from a system's perspective, or indirectly from an environment's perspective. In the former case, the methodology labeled as social autopoiesis is developed by Niklas Luhmann in adopting Maturana's and Varela's biological approach for social science. In contrast, in the latter case methodologies applied by Ludwig Bertalanffy's general systems theory, Norbert Wiener's cybernetics, or Claude Shannon's mathematical theory of communication consider interobjective relations from a more general and external perspective taken by the researcher (Brier 2008, 207-210; Esbjörn-Hargens and Zimmerman 2009, 255-56).

The added value of the AQAL model in general and the IMP in particular is to function as an orienting map which informs research programs when indicated about their blind spots: "One of the basic premises of Integral Research is that any phenomena under investigation should be examined simultaneously or concurrently from 1st, 2nd, and 3rd person methodologies" (EsbjörnHargens 2006, 89).

As a prime example, Esbjörn-Hargens and Zimmerman (2009) provide a comprehensive analysis of the ontological, epistemological, and methodological dimensions of more than 200 different approaches to ecology and environmental sciences based on integral theory and the AQAL framework. In $\mathrm{KO}$ research, cybersemiotics might be considered as one of the most comprehensive approaches since all three value spheres and its validity claims or, likewise, all "quadrants" are explicitly taken into account in order to put forward a transdisciplinary integration of knowledge (Brier 1996, 1997, 2000, 2003, 2008). In this regard, cybersemiotics can be seen as an attempt to combine the third-person-perspective commonly taken by approaches oriented in cybernetics or systems theory, and the second-person-perspective commonly taken by approaches oriented in semiotics or hermeneutics; and at the same time to integrate the first-person-perspective of phenomenology often neglected in KO theory. EsbjörnHargens and Zimmerman (2009, 501) write:
Cybersemiotics has been developed by Søren Brier in the 1990s as an integration of phenomenology, biosemiotics, social autopoiesis, and information science. Cybersemiotics is a transdisciplinary nonreductionist approach to cognition and communication that studies the exchange of information and meaning in organisms... . Zones: 1, 3, 5, 7.

The cybersemiotic approach, however, seems to disclose some "blind spots" by itself as an IMP analysis is able to demonstrate. While the traditional empirical sciences (zones 6 and 8) are taken for granted and function as reference points for a criticism of reductionism, the more structuralist and reconstructive methodologies (zones 2 and 4), which are commonly applied to the long-term development of cognition, seem to be underrepresented, at least at the human level which is crucial for KO.

This is somewhat surprising since cybersemiotics, quite similar to integral theory, is heavily influenced by evolutionary semiotics of Charles S. Peirce and based on a level model of being and knowing (Combs and Brier, 2000; Brier 2003). In this view, the emergent levels of complexity from cells to frogs to elephants to human beings are simultaneously seen as both levels of being and levels of knowing ("To live is to know!"). Furthermore, Brier emphasizes the importance of a developmental approach even within the human level: "If the human mind did not 'fall from the sky' then it developed through evolution" (Brier 2008, 428). However, in order to reconstruct the long-term development of human cognition in history such as the shift "from mythos to logos" (Brier 2008, 129), we have to consider not only the biological evolution (phylogenesis) but the cultural development (historiogenesis) (Dux 2011). The latter requires reconstructive methodologies since the transitions of human consciousness from one level to another, transitions of deep structures or modes of thinking, are hardly accessible from the inside by direct methodologies such as phenomenology (zone 1) or hermeneutics (zone 3), but demand a distant look from the outside by indirect methodologies such as developmental structuralism (zone 2) or variants of ethnomethodology (zone 4) (Habermas 1984, 102-142).

Thus for KO theory, reconstructive approaches to human knowledge based on historico-genetical methodologies seem to be promising, in particular, the more advanced approaches rooted in the Piagetian tradition (Piaget 1973; Hallpike 1979; Habermas 1984; Campbell and Bickhard 1986; Piaget and Garcia 1989; Kitchener 1987; Oesterdiekhoff 1997; Dux 2011; Wenzel 2000; Wilber 2000a, 2000b; Robinson 2004; Combs 2005; Tsou 2006; Bammé 2011; Kleineberg 2012; Seiler 2012).

In summary, a transdisciplinary KOS considered as a “"one place' classification” (Hjørland 2008, 338) should 
indeed be based on phenomena, although, the underlying phenomenon concept must be re-conceptualized as a triadic relation. In other words, in order to localize a phenomenon we have at least to determine three dimensions of knowledge (for the concept of "kosmic address" introduced by Wilber see Esbjörn-Hargens and Zimmer$\operatorname{man} 2009,158)$ :

\section{Phenomenon $=$ WHAT $\times$ WHO $\times$ HOW}

As a consequence, within library and information science an old desideratum can be addressed (Bies 1992): next to a descriptive indexing based on syntactics (e.g., the grammar of bibliography including authority control or alphabetical order) and a subject indexing based on semantics (e.g., subject, aboutness, topicality), there is a need for a context indexing based on pragmatics (e.g., perspective, mode of thinking, paradigm, injunction) which includes both a viewpoint indexing (theory) and a method indexing (praxis) (see Figure 8).

In this paper, it is argued that an adequate implementation of contextualism with regard to human knowledge must be based on a triadic concept of phenomenon and solid organizing principles for each dimension. Three of them are presented here, namely the traditional principle of "levels of being" (ontology), as well as two novel principles termed "levels of knowing" (epistemology) and "integral methodological pluralism" (methodology). Insofar, the desideratum of a systematic organization of epistemic context seems to be redeemable at least in principle, although, the development of specific applications of the proposed WHAT-WHO-HOW approach to knowledge organization will be a matter of further discussion.

\subsection{Conclusion}

In essence, the parable of the blind men and the elephant is keeping its moral in both the weak and the strong interpretation. If you have eyes to see, you will get the big picture. The "modernist" exegetes, however, seem to ignore the interpretive turn in the philosophy of science and the now widely accepted constructivism and perspectivism with regard to human knowledge. For this reason, the weak interpretation is only valid within a very limited scope in which the blind men already have a shared worldview and pre-understanding. Only in this special case, the descriptions of the elephant could be integrated into a coherent whole, though a limited whole, and this seems to be the wisdom of the parable, is nothing else but blindness.

In other words, under the conditions of postmetaphysical thinking, a strong interpretation is the only option. The "postmodernist" exegetes would legitimately emphasize that the blind men with their divergent theoretical and metatheoretical frames of reference as well as their methodological pluralism (co-)construct the phenomena under investigation. The question, however, how to make the blind men see again even in this case seems to be completely abandoned by a "postmodernism" which seeks to arrange itself with the aporia of relativism. Indeed, the answer appears to be as simple as conclusive. From a strong interpretation's view, the big picture could be seen in following two steps: Firstly, we should be able to take alternative perspectives by means of sufficient reconstructions of foreign worldviews; and secondly, we should be able to interrelate all these reconstructed perspectives in a systematic and non-relativistic way.

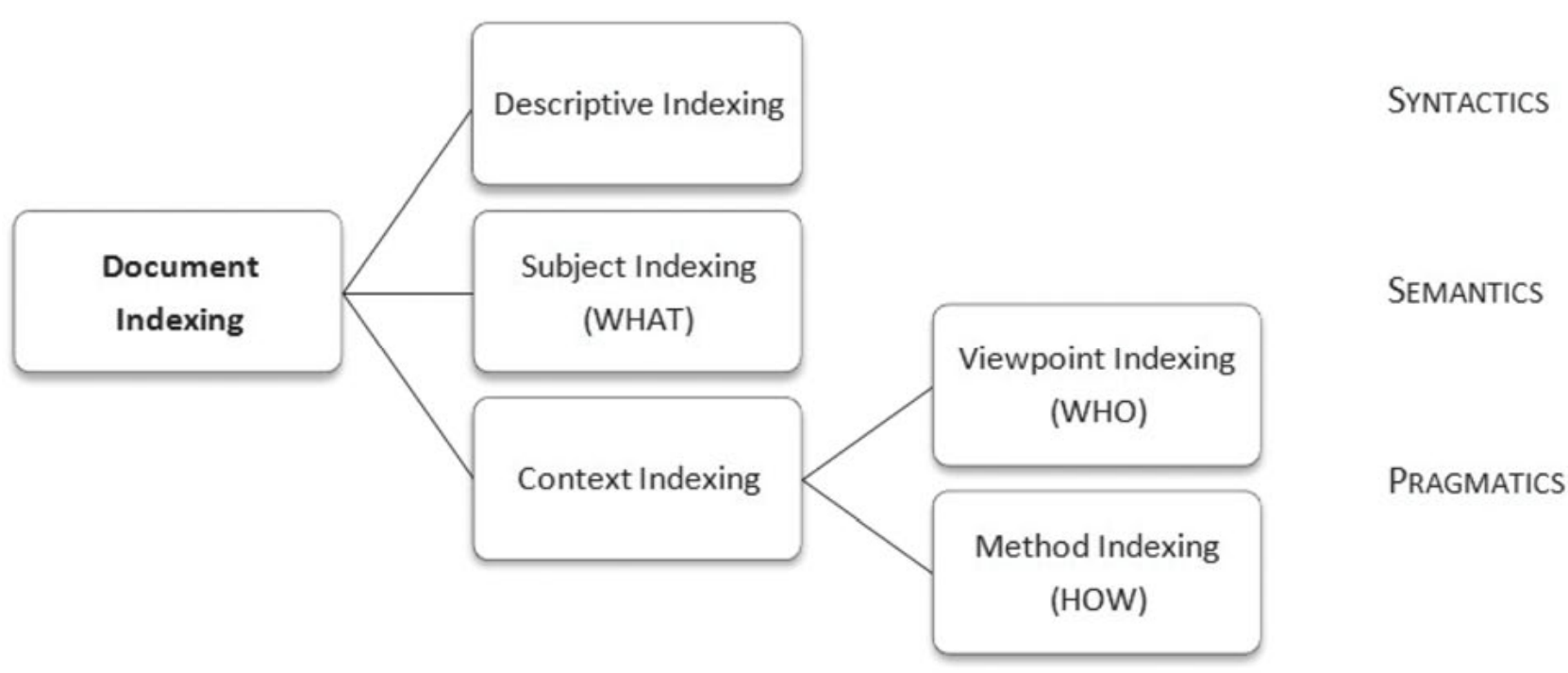

Figure 8. The WHAT-WHO-HOW approach to document indexing 
M. Kleineberg. The Blind Men and the Elephant: Towards an Organization of Epistemic Contexts

This is exactly what the historico-genetic approach in sociology of knowledge is about. Here, the analysis of worldview structures and their transformations in history leads to the concept of levels of knowing considered as developmental cognitive stages of increasing complexity and integration. In other words, this theory of knowledge offers a novel organizing principle as a foundation for the proposed context indexing.

Thus these preliminary thoughts about a future context indexing seek to challenge both camps of $\mathrm{KO}$ research. On the one hand, Hjørland's (2008) request to Szostak to offer new arguments for a phenomena-based KOS is addressed by means of the proposed three-dimensional concept of phenomenon. On the other hand, the universal scope of KO how it is defended in Szostak's (2008b) reply is addressed by means of the proposed ontologicalepistemological concept of reality which already includes the pluralism of perspectives.

In this paper, it is argued that if the increasingly accepted precondition that human knowledge is always knowledge in context can be taken for granted, then a systematic organization of epistemic contexts is mandatory for $\mathrm{KO}$ theory, in particular, for any phenomena-based approach. The main contribution of this paper might be seen in the revision of the underlying concept of phenomenon which is re-conceptualized as a triadic relation between the WHAT, the WHO, and the HOW of knowledge in order to implement perspectivism and contextualism in the theory of KO. Admittedly, previous phenomena-based approaches to $\mathrm{KO}$ are not completely outdated or invalid but they have to integrate the epistemological (including methodological) dimension not merely as another facet but as an constitutive and equivalent component of KOSs. Within the "modernist" camp (classification-as-ontology) optimism seems to predominate in regard to a "universal classification of the phenomena studied by scholars and the theories and methods applied by scholars" (Szostak quoted in ISKO Italy 2007, 7), although, the undeniable constructivism of human knowledge is hardly appreciated, which is why the level of reflection offered by recent philosophy of science is out of reach. In contrast, there is a prevailing skepticism within the "postmodernist" camp (classification-as-epistemology) with regard to a transdisciplinary organization of knowledge because the notion of reality is literally lost since the constructivism of human knowledge is seen as open to arbitrary and incommensurable fantasies.

As an alternative, this paper proposes an integrative approach which one might label as "classification-asontology/epistemology" based on a triadic phenomenon concept and on three fundamental organizing principles, namely the "levels of being" (ontology), the "levels of knowing" (epistemology), and the "integral methodologi- cal pluralism" (methodology) in order to avoid the common fallacy that epistemic pluralism implies epistemic relativism.

The end of the story is that the elephant as well as the parable itself is like every phenomenon or narrative open to different interpretations. Each of them might be partially true and none of them might be finally privileged, but this does not mean that all taken perspectives are equally valid or that we are not able to organize them in a meaningful way.

\section{References}

Alexander, Charles N. and Langer, Ellen J. 1990. Higher stages of human development: perspectives on adult growth. New York, Oxford: Oxford University Press.

Austen, Derek. 1969. The theory of integrative levels reconsidered as a basis for a general classification. In Classification Research Group, ed., Classification and information control. London: The Library Association, pp. 81-95.

Bammé, Arno. 2011. Homo occidentalis: Von der Anschaunng zur Bemächtigung der Welt. Zäsuren abendländischer Epistemologie. Weilerswist: Velbrück.

Begthol, Clare. 1998. Knowledge domains: multidisciplinarity and bibliographic systems. Knowledge organization 25: 1-12.

Bickhard, Mark. H. 1993. On why constructivism does not yield relativism. Journal of experimental and theoretical artificial intelligence 5: 275-84.

Bies, Werner. 1992. Linguistische pragmatik: Eine vernachlässigte referenzdisziplin der inhaltserschließung. In Gödert, Winfried, ed., Kognitive ansätre zum ordnen und darstellen von wissen. Frankfurt am Main: Indeks Verlag, pp. 207-16.

Blitz, David. 1992. Emergent evolution: Qualitative novelty and levels of reality. Dordrecht, Boston, London: Kluwer.

Brier, Søren. 1996. Cybersemiotics: A new interdisciplinary development applied to the problems of knowledge organization and document retrieval in information science. Journal of documentation 52: 296-344.

Brier, Søren. 1997. What is a possible ontological and epistemological framework for a true universal information science'?: The suggestion of cybersemiotics. World futures 49: 287-308.

Brier, Søren. 2000. Trans-scientific frameworks of knowing: Complementary views of the different types of human knowledge. Systems research and behavioral science 17: 433-58.

Brier, Søren. 2003. Information seen as part of the development of living intelligence: The five-leveled cybersemiotic framework for FIS. Entropy 5: 88-99. 
Brier, Søren. 2008. Cybersemiotics: Why information is not enough. Toronto: University of Toronto Press.

Campbell, Robert L. and Bickhard, Mark H. 1986. Knowing levels and developmental stages. Basel, New York: Karger.

Combs, Allan. 2005. Consciousness explained better: Towards an integral understanding of the multifaceted nature of consciousness. St. Paul: Paragon House.

Combs, Allan and Brier, Søren. 2000. Signs, information, and consciousness. Systems 5: 15-24.

Combs, Allan and Esbjörn-Hargens, Sean. 2006. An integral tour of consciousness studies. Journal of integral theory and practice 1: 162-82.

Dahlberg, Ingetraut. 1974. Grundlagen universaler wissensordnung: Probleme und möglichkeiten eines universalen klassifikationssystems des wissens. Pullach: Verlag Dokumentation.

Dahlberg, Ingetraut. 2008. The information coding classification (ICC): A modern, theory-based fully-faceted, universal system of knowledge fields. Axiomathes 18: 161-76.

Dervin, Brenda. 2003. Given a context by any other name: Methodological tools for taming the unruly beast. In Dervin, Brenda, Foreman-Wernet, Lois and Lauterbach, Eric, eds., Sense-making methodology reader: Selected writings of Brenda Dervin. Creskill: Hampton Press, pp. 111-32.

Dousa, Thomas M. 2009. Evolutionary order in the classification theories of C. A. Cutter \& E. C. Richardson: Its nature and limits. In Jacob, Elin K. and Kwasnik, Barbara, eds., Proceedings from North American Symposium on Knowledge Organization Vol. 2. Syracuse, NY, pp. 76-90.

Dux, Günter. 2011. Historico-genetic theory of culture: On the processual logic of cultural change. Bielefeld: Transcript.

Esbjörn-Hargens, Sean. 2006. Integral research: A multimethod approach to investigating phenomena. Constructivism in the human sciences 11: 79-107.

Esbjörn-Hargens, Sean. 2010. An overview of integral theory: An all-inclusive framework for the 21st century. In Esbjörn-Hargens, Sean, ed., Integral theory in action. New York: SUNY Press, pp. 33-61.

Esbjörn-Hargens, Sean and Zimmerman, Michael. 2009. Integral ecology: Uniting multiple perspectives on the natural world. Boston, London: Integral Books.

Feibleman, James K. 1954. Theory of integrative levels. British journal for the philosophy of science 5: 59-66.

Feinberg, Todd E. 2011. The nested neural hierarchy and the self. Consciousness and cognition 20: 4-15.

Fetz, Reto L. 1982. Naturdenken beim kind und bei Aristoteles: Fragen einer genetischen ontologie. Tijdschrift voor filosofie 44: 473-513.

Foskett, Douglas J. 1978. The theory of integrative levels and its relevance to the design of information systems. Aslib proceedings 30: 202-8.
Gebser, Jean. 1985. The ever-present origin. Translated by Noel Barstad and Algis Mickunas. Athens, Ohio: Ohio University Press.

Gnoli, Claudio. 2008. Categories and facets in integrative levels. Axiomathes 18: 177-92.

Gnoli, Claudio. 2011. Animals belonging to the emperor: Enabling viewpoint warrant in classification. In Landry, Patrice, Bultrini, Leda, O'Neill, Edward T. and Roe, Sandra K., eds., Subject access: Preparing for the future. Berlin, Boston: De Gruyter, pp. 91-100.

Gnoli, Claudio. 2012. Metadata about what?: Distinguishing between ontic, epistemic, and documental dimensions in knowledge organization. Knowledge organization 39: 268-75.

Gnoli, Claudio and Poli, Roberto. 2004. Levels of reality and levels of representation. Knowledge organization 31: 151-60.

Gnoli, Claudio and Szostak, Richard. 2009. Beyond aboutness: Classifying causal links in the service of interdisciplinarity. Advances in classification research online 20. Available https://journals.lib. washington.edu/index. php/acro/article/view/12882

Goldmann, Lucien. 1975. Towards a sociology of the novel. Translated by Alan Sheridan. London: Tavistock Publications.

Habermas, Jürgen. 1984. Theory of communicative action. Vol. I: Reason and the rationalization of society. Translated by Thomas McCarthy. Boston: Beacon Press.

Habermas, Jürgen. 1992. Postmetaphysical thinking: philosophical essays. Translated by William M. Hohengarten. Cambridge: MIT Press.

Habermas, Jürgen. 2009. Philosophische texte. Vol. V: Kritik der vernunft. Frankfurt am Main: Suhrkamp.

Hallpike, Christopher R. 1979. The foundations of primitive thought. Oxford: Clarendon Press.

Hartmann, Nicolai. 1953. New ways of ontology. Translated by Reinhard C. Kubn. Chicago: Regnery.

Hjørland, Birger. 2008. Core classification theory: A reply to Szostak. Journal of documentation 64: 333-42.

Hjørland, Birger. 2009. Concept theory. Journal of the American Society for Information Science and Technology 60: 1519-36.

Hjørland, Birger. 2010. Answer to professor Szostak (concept theory). Journal of the American Society for Information Science and Technology 61: 1078-80.

Hjørland, Birger and Hartel, Jenna. 2003. Afterword: ontological, epistemological and sociological dimensions of domains. Knowledge organization 30: 239-44.

Hjørland, Birger and Pedersen, Karsten N. 2005. A substantive theory of classification for information retrieval. Journal of documentation 61: 582-97. 
M. Kleineberg. The Blind Men and the Elephant: Towards an Organization of Epistemic Contexts

Huckaby, Sarah A. S. 1972. An enquiry into the theory of integrative levels as the basis for a generalized classification scheme. Journal of documentation 28: 97-106.

ISKO Italy. 2007. León manifesto. Knowlegde organization 34: 6-8.

Jacob, Elin K. 2000. The legacy of pragmatism: implications for knowledge organization in a pluralistic universe. In Beghtol, Claire, Howarth, Lynne C and Williamson, Nancy Joyce., eds., Dynamism and stability in knowledge organization: Proceedings of the Sixth International ISKO Conference (Toronto, Canada, July 10-13, 2000). Advances in knowledge organization, no. 7. Würzburg: Ergon., pp.16-22.

Jantsch, Erich. 1980. The self-organizing universe: scientific and buman implications of the emerging paradigm of evolution. Oxford, New York: Pergamon Press.

Kaipainen, Mauri and Hautamäki, Antti. 2011. Epistemic pluralism and multi-perspective knowledge organization: Explorative conceptualization of topical content domains. Knowledge organization 38: 503-14.

Kitchener, Richard F. 1987. Genetic epistemology, equilibration and the rationality of scientific change. Studies in history and philosophy of science 18: 339-66.

Klein, Julie T. 1990. Interdisciplinarity: history, theory, and practice. Detroit: Wayne State University Press.

Kleineberg, Michael. 2012. Die elementaren formen der klassifikation: Ein strukturgenetischer beitrag zur informationsgeschichte. Berliner handreichungen zur bibliotheks- und informationswissenschaft 325. Available http:// edoc.hu-berlin.de/series/berliner-handreichungen/ 2012-325/PDF/325.pdf.

Lerner, Richard M. and Kauffman, Marjorie B. 1985. The concept of development in contextualism. Developmental review 5: 309-33.

Mai, Jens-Erik. 1999. A postmodern theory of knowledge organization. ASIS proceedings 36: 547-56.

Mai, Jens-Erik. 2003. The future of general classification. Cataloging and classification quarterly 37: 3-12.

Mai, Jens-Erik. 2004. Classification in context: Relativity, reality, and representation. Knowledge organization 31: 3948.

Mai, Jens-Erik. 2011. The modernity of classification. Journal of documentation 67: 710-30.

Neuhäuser, Gabriele. 2003. Konstruktiver realismus: Jean Piagets naturalistische Erkenntnistheorie. Würzburg: Königshausen und Neumann.

Nicolescu, Basarab. 2010. Methodology of transdisciplinarity: Levels of reality, logic of the included middle and complexity. Transdisciplinary journal of engineering and science 1: 19-38.

Oesterdiekhoff, Georg. 1997. Kulturelle bedingungen kognitiver entwicklung: Der strukturgenetische ansatz in der soziologie. Frankfurt am Main: Suhrkamp.
Olson, Hope A. 2010. Social influences on classification. In Bates, Marcia J. and Maack, Mary N., eds., Encyclopedia of library and information sciences. Vol. V. Boca Raton: CRC Press, pp. 4806-10.

Onion, Patrick and Orange, Graham. 2002. The three K's: A model for knowledge that supports ontology and epistemology. Proceedings of the 6th World Multi-Conference on Systemics, Cybernetics and Informatics. Available http:// citeseerx.ist.psu.edu/viewdoc/download?doi=10.1.1. $15.4295 \&$ rep $=$ rep1\&type $=$ pdf.

Piaget, Jean. 1973. Die entwicklung des erkennens. Vol. I-III. Stuttgart: Klett.

Piaget, Jean and Garcia, Rolando. 1989. Psychogenesis and the bistory of science. New York: Columbia University Press.

Poli, Roberto. 1996. Ontology for knowledge organization. In Green, Rebecca, ed., Knowledge organization and change. Frankfurt am Main: Indeks Verlag, pp. 313-9.

Poli, Roberto. 1998. Levels. Axiomathes 1/2: 197-211.

Poli, Roberto. 2001. Basic problems of the theory of integrative levels of reality. Axiomathes 12: 261-83.

Poli, Roberto. 2006. The theory of levels of reality and the difference between simple and tangled hierarchies. In Minati, Gianfranco, Pessa, Eliano and Abram, Mario, eds., Systemics of emergence: research and development. New York: Springer, pp. 715-22.

Quilley, Stephen. 2010. Integrative levels and 'the great evolution': Organicist biology and the sociology of Norbert Elias. Journal of classical sociology 10: 391-419.

Robinson, Richard J. 2004. The bistory of buman reason. London: Prometheus Research Group.

Rötzer, Andreas. 2003. Die einteilung der wissenschaften: Analyse und typologisierung von wissenschaftsklassifikationen. Available http://endo-management.de/documents/Andreas Roetzer.pdf.

Seiler, Thomas B. 2012. Evolution des wissens. Vol. I-II. Berlin: LIT Verlag.

Skrbina, David. 2005. Panpsychism in the west. Cambrigde, London: MIT Press.

Smiraglia, Richard P. 2012. Introduction: theory, knowledge organization, epistemology, culture. In Smiraglia, Richard P. and Lee, Hur-Li, eds., Cultural frames of knowledge. Würzburg: Ergon, pp. 1-17.

Spiteri, Louise F. 1995. The classification research group and the theory of integrative levels. The Katharine Sharp review 1. Available: http://mirrored.ukoln.ac.uk/lisjournals/review/review/summer1995/spiteri.html. Accessed 22 August 2013.

Svenonius, Elaine. 2004. The epistemological foundations of knowledge representation. Library trends 52: 571-87.

Szostak, Richard. 2003. Classifying schorlarly theories and methods. Knowledge orgaization 30: 20-35.

Szostak, Richard. 2007. Modernism, postmodernism, and interdisciplinarity. Issues in integral studies 25: 32-83. 
Szostak, Richard. 2008a. Classification, interdisciplinarity, and the study of science. Journal of documentation 64: 319-32.

Szostak, Richard. 2008b. Interdisciplinarity and classification: A reply to Hjørland. Journal of documentation 64: 479-81.

Szostak, Richard. 2010. Comments on Hjørland's concept theory. Journal of the American Society for Information Science and Technology 61: 1076-7.

Talja, Sanna et al. 1999. The production of context in information seeking research: A metatheoretical view. Information processing and management 35: 751-63.

Thompson, William I. 1996. Coming into being: Artifacts and texts in the evolution of consciousness. New York: St. Martin's Press.

Tobach, Ethel. 1987. Integrative levels in comparative psychology of cognition, language, and consciousness. In Greenberg, Gary and Tobach, Ethel, eds., Cognition, language and consciousness: integrative levels. London: Erlbaum, pp. 239-67.
Tsou, Jonathan Y. 2006. Genetic epistemology and Piaget's philosophy of science: Piaget vs. Kuhn on scientific progress. Theory and psychology 16: 203-24.

Weinberg, Bella H. 1988. Why indexing fails the researcher. The indexer 16: 3-6.

Wenzel, Ulrich. 2000. Vom ursprung zum prozess: Zur rekonstruktion des Aristotelischen kausalitätsverständnisses und seiner wandlungen bis zur neuzeit. Opladen: Leske und Budrich.

Wilber, Ken. 1997. An integral theory of consciousness. Journal of consciousness studies 4: 71-92.

Wilber, Ken. 2000a. Integral psychology: Consciousness, spirit, psychology and therapy. Boston, London: Shambhala.

Wilber, Ken. 2000b. Sex, ecology and spirituality: The spirit of evolution. Boston, London: Shambhala. 


\title{
KNOWLEDGE ORGANIZATION
}

\author{
Official Bi-Monthly Journal of the International Society for Knowledge Organization
}

ISSN $0943-7444$

International Journal devoted to Concept Theory, Classification, Indexing and Knowledge Representation

\section{Publisher}

ERGON-Verlag GmbH, Keesburgstr. 11, D-97074 Würzburg Phone: +49(0)931 280084; FAX +49 (0)931 282872

E-mail: service@ergon-verlag.de; http://www.ergon-verlag.de

\section{Editor-in-chief (Editorial office)}

Dr. Richard P. SMIRAGLIA (Editor-in-Chief), School of Information Studies, University of Wisconsin, Milwaukee, Northwest Quad Building B, 2025 E Newport St., Milwaukee, WI 53211 USA. E-mail: smiragli@uwm.edu

\section{Instructions for Authors}

Manuscripts should be submitted electronically (in Word format) in English only via email to the editor-in chief and should be accompanied by an indicative abstract of 150 to 200 words. Manuscripts of articles should fall within the range 6,000-10,000 words. Longer manuscripts will be considered on consultation with the editor-in-chief.

A separate title page should include the article title and the author's name, postal address, and E-mail address, if available. Only the title of the article should appear on the first page of the text.

To protect anonymity, the author's name should not appear on the manuscript, and all references in the body of the text and in footnotes that might identify the author to the reviewer should be removed and cited on a separate page.

Criteria for acceptance will be appropriateness to the field of the journal (see Scope and Aims), taking into account the merit of the contents and presentation. The manuscript should be concise and should conform as much as possible to professional standards of English usage and grammar. Manuscripts are received with the understanding that they have not been previously published, are not being submitted for publication elsewhere, and that if the work received official sponsorship, it has been duly released for publication. Submissions are refereed, and authors will usually be notified within 6 to 10 weeks.

The text should be structured by numbered subheadings. It should contain an introduction, giving an overview and stating the purpose, a main body, describing in sufficient detail the materials or methods used and the results or systems developed, and a conclusion or summary.

Footnotes are accepted only in rare cases and should be limited in number; all narration should be included in the text of the article. Paragraphs should include a topic sentence and some developed narrative; a typical paragraph has several sentences. Italics may not be used for emphasis. Em-dashes should not be used as substitutes for commas.

Italics should not be used for emphasis. Em-dashes should be used as substitutes for commas. Paragraphs should include a topic sentence and some developed narrative. A typical paragraph has several sentences.

Reference citations within the text should have the following form: (Author year). For example, (Jones 1990). Specific page numbers are required for quoted material, e.g. (Jones 1990, 100). A citation with two authors would read (Jones and Smith, 1990); three or more authors would be: (Jones et al., 1990). When the author is mentioned in the text, only the date and optional page number should appear in parenthesis e.g. According to Jones (1990), ...
References should be listed alphabetically by author at the end of the article. Author names should be given as found in the sources (not abbreviated). Journal titles should not be abbreviated. Multiple citations to works by the same author should be listed chronologically and should each include the author's name. Articles appearing in the same year should have the following format: "Jones 2005a, Jones 2005b, etc." Issue numbers are given only when a journal volume is not throughpaginated.

Examples:

Dahlberg, Ingetraut. 1978. A referent-oriented, analytical concept theory for INTERCONCEPT. International classification 5: 142-51.

Howarth, Lynne C. 2003. Designing a common namespace for searching metadata-enabled knowledge repositories: an international perspective. Cataloging \& classification quarterly 37n1/2: 173-85.

Pogorelec, Andrej and Šauperl, Alenka. 2006. The alternative model of classification of belles-lettres in libraries. Knowledge organization 33: 204-14.

Schallier, Wouter. 2004. On the razor's edge: between local and overall needs in knowledge organization. In McIlwaine, Ia C. ed., Knowledge organization and the global information society: Proceedings of the Eighth International ISKO Conference 13-16 July 2004 London, UK. Advances in knowledge organization 9. Würzburg: Ergon Verlag, pp. 269-74.

Smiraglia, Richard P. 2001. The nature of 'a work': implications for the organization of knowledge. Lanham, Md.: Scarecrow.

Smiraglia, Richard P. 2005. Instantiation: Toward a theory. In Vaughan, Liwen, ed. Data, information, and knowledge in a networked world; Annual conference of the Canadian Association for Information Science ... London, Ontario, June 2-4 2005. Available http://www.cais-acsi.ca/2005proceedings.htm.

Illustrations should be kept to a necessary minimum and should be embedded within the document. Photographs (including color and halftone) should be scanned with a minimum resolution of $600 \mathrm{dpi}$ and saved as .jpg files. Tables and figures should be embedded within the document. Tables should contain a number and title at the bottom, and all columns and rows should have headings. All illustrations should be cited in the text as Figure 1, Figure 2, etc. or Table 1, Table 2, etc.

The entire manuscript should be double-spaced, including notes and references.

Upon acceptance of a manuscript for publication, authors must provide a wallet-size photo and a one-paragraph biographical sketch (fewer than 100 words). The photograph should be scanned with a minimum resolution of $600 \mathrm{dpi}$ and saved as a .jpg file.

\section{Advertising}

Responsible for advertising: ERGON-Verlag GmbH, Keesburgstr. 11, 97074 Würzburg (Germany).

(C) 2013 by ERGON-Verlag GmbH.

All Rights reserved.

KO is published bi-monthly by ERGON-Verlag GmbH.

- The price for the print version is $€ 229,00 /$ ann. including airmail delivery.

- The price for the print version plus access to the online version (PDF) is $€ 258,00 /$ ann. including airmail delivery. 


\section{Scope}

The more scientific data is generated in the impetuous present times, the more ordering energy needs to be expended to control these data in a retrievable fashion. With the abundance of knowledge now available the questions of new solutions to the ordering problem and thus of improved classification systems, methods and procedures have acquired unforeseen significance. For many years now they have been the focus of interest of information scientists the world over.

Until recently, the special literature relevant to classification was published in piecemeal fashion, scattered over the numerous technical journals serving the experts of the various fields such as:

\author{
philosophy and science of science \\ science policy and science organization \\ mathematics, statistics and computer science \\ library and information science \\ archivistics and museology \\ journalism and communication science \\ industrial products and commodity science \\ terminology, lexicography and linguistics
}

Beginning in 1974, KNOWLEDGE ORGANIZATION (formerly INTERNATIONAL CLASSIFICATION) has been serving as a common platform for the discussion of both theoretical background questions and practical application problems in many areas of concern. In each issue experts from many countries comment on questions of an adequate structuring and construction of ordering systems and on the problems of their use in opening the information contents of new literature, of data collections and survey, of tabular works and of other objects of scientific interest. Their contributions have been concerned with

(1) clarifying the theoretical foundations (general ordering theory/ science, theoretical bases of classification, data analysis and reduction)

(2) describing practical operations connected with indexing/classification, as well as applications of classification systems and thesauri, manual and machine indexing

(3) tracing the history of classification knowledge and methodology

(4) discussing questions of education and training in classification

(5) concerning themselves with the problems of terminology in general and with respect to special fields.

\section{Aims}

Thus, KNOWLEDGE ORGANIZATION is a forum for all those interested in the organization of knowledge on a universal or a domainspecific scale, using concept-analytical or concept-synthetical approaches, as well as quantitative and qualitative methodologies. KNOWLEDGE ORGANIZATION also addresses the intellectual and automatic compilation and use of classification systems and thesauri in all fields of knowledge, with special attention being given to the problems of terminology.

KNOWLEDGE ORGANIZATION publishes original articles, reports on conferences and similar communications, as well as book reviews, letters to the editor, and an extensive annotated bibliography of recent classification and indexing literature.

KNOWLEDGE ORGANIZATION should therefore be available at every university and research library of every country, at every information center, at colleges and schools of library and information science, in the hands of everybody interested in the fields mentioned above and thus also at every office for updating information on any topic related to the problems of order in our information-flooded times.

KNOWLEDGE ORGANIZATION was founded in 1973 by an international group of scholars with a consulting board of editors representing the world's regions, the special classification fields, and the subject areas involved. From 1974-1980 it was published by K.G. Saur Verlag, München. Back issues of 1978-1992 are available from ERGONVerlag, too.

As of 1989, KNOWLEDGE ORGANIZATION has become the official organ of the INTERNATIONAL SOCIETY FOR KNOWLEDGE ORGANIZATION (ISKO) and is included for every ISKOmember, personal or institutional in the membership fee (US \$ 55/ US \$110).

Rates: From 2013 on for 6 issues/ann. (including indexes) $€ 229,00$ (forwarding costs included) for the print version resp. $€ 258,00$ for the print version plus access to the online version (PDF). Membership rates see above.

ERGON-Verlag GmbH, Keesburgstr. 11, D-97074 Würzburg; Phone: +49 (0)931 280084; FAX +49 (0)931 282872; E-mail: service@ergon-verlag.de; http://www.ergon-verlag.de

Founded under the title International Classification in 1974 by Dr. Ingetraut Dahlberg, the founding president of ISKO. Dr. Dahlberg served as the journal's editor from 1974 to 1997 , and as its publisher (Indeks Verlag of Frankfurt) from 1981 to 1997.

The contents of the journal are indexed and abstracted in Social Sciences Citation Index, Web of Science, Information Science Abstracts, INSPEC, Library and Information Science Abstracts (LISA), Library, Information Science \& Technology Abstracts (EBSCO), Library Literature and Information Science (Wilson), PASCAL, Referatimyi Zhurnal Informatika, and Sociological Abstracts. 